\title{
Between Taxes, Criminal Law and Health Care: The Fight Against Illicit Tobacco Trade in Germany
}

\author{
Marc Engelhart
}

\section{Contents}

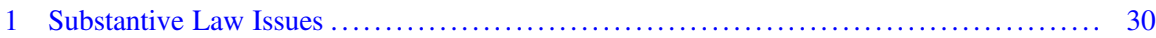

1.1 Legal Architecture Related to the Illicit Trade of Tobacco Products ............. 30

1.1.1 Relevant Offences and Their Features ........................... 30

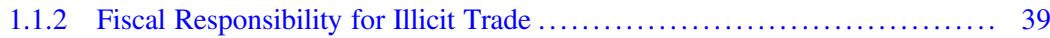

1.1.3 Relation Between Criminal and Administrative/Fiscal Responsibility ....... 46

1.2 Relations Between Criminalization of Illicit Trade of Tobacco and Other Types of Economic Crimes ............................................. 46

1.3 Aggravating Cases of Illicit Trade of Tobacco Products .................... 47

1.3.1 Professional, Violent or Organized Smuggling, § 373 AO ............... 47

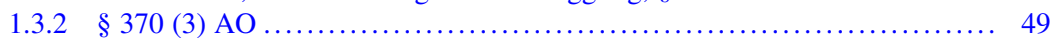

1.4 Legal Responsibility of Individuals for Illicit Trade of Tobacco Products ......... 49

1.5 Sanctions Applicable for Illicit Trade of Tobacco Products (Individuals) ......... 50

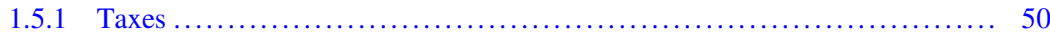

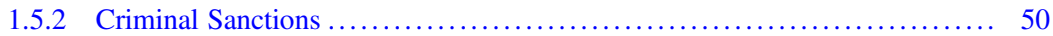

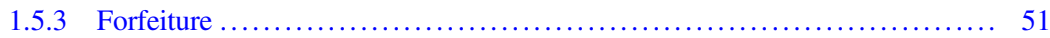

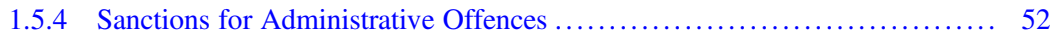

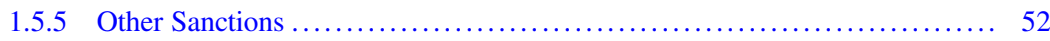

1.6 Liability and Sanctions for Illicit Trade of Tobacco Products (Legal Persons) ...... 53

1.7 Disposal or Destruction of Confiscated Tobacco Products .................... 53

1.8 WTO FCTC and the 2012 Protocol .................................... 54

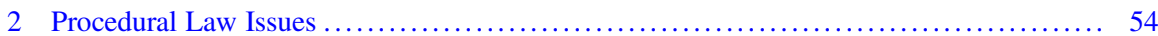

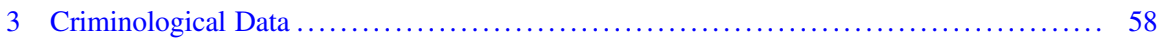

3.1 Investigation of Illicit Trade of Tobacco Products ........................ 58

3.2 Prosecution/Convictions in Cases of Illicit Trade of Tobacco Products ............ 60

3.3 Financial Impact of Illicit Trade of Tobacco Products ...................... 62

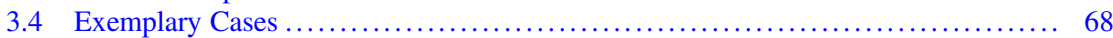

3.5 Features of Illicit Trade of Tobacco Products ............................ 69

3.6 Characteristics of Perpetrators of Illicit Trade of Tobacco .................... 71

3.7 Trends in Illicit Trade of Tobacco Products .............................. 71

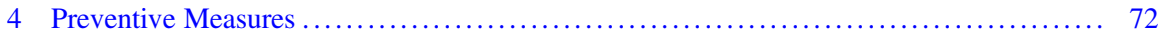

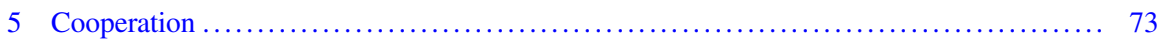

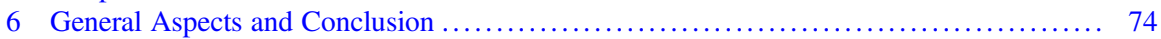

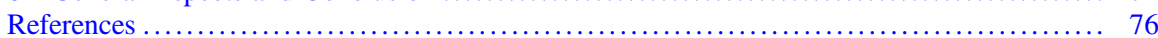

M. Engelhart ( $\square)$

Max Planck Institute for the Study of Crime, Security and Law, Freiburg, Germany 


\begin{abstract}
The German chapter deals with illicit trade of tobacco goods in Germany, its regulation by law, the authorities responsible for preventive and repressive aspects of fighting illicit trade and the procedures that apply as well as the relevance of illicit trade in practice. Repressive regulations in the field can mainly be found in tax criminal law. The specific area of tobacco tax criminal law (Tabaksteuerstrafrecht) is a special matter of excise tax criminal law (Verbrauchssteuerstrafrecht). Tax criminal law follows the general criminal law rules and therefore the criminal courts are responsible, which means that their point of view can differ from that of the fiscal courts. The main offense in tax criminal law is $\S 370 \mathrm{AO}$ (tax evasion), which is accompanied by special regulations in the Tabaksteuergesetz (Tobacco tax law-TabStG). In practice, besides the criminal justice authorities the custom authorities play a major role in investigating tobacco crimes, mainly the Customs Criminal Investigation Office (Zollkriminalamt-ZKA) and its local offices.
\end{abstract}

\title{
1 Substantive Law Issues
}

\subsection{Legal Architecture Related to the Illicit Trade of Tobacco Products}

\subsubsection{Relevant Offences and Their Features}

Illicit trade of tobacco goods is covered in Germany mainly by tax criminal law. The specific area of tobacco tax criminal law (Tabaksteuerstrafrecht) is a special matter of excise tax criminal law (Verbrauchssteuerstrafrecht) being a special matter of tax criminal law. This means it is a highly specialized field of law only few experts are familiar with but not the common criminal lawyer. This creates problems, e.g., when prosecutors, judges and the defense have to deal with a case in the ordinary criminal proceedings. Tax criminal law is criminal law in regard to a specific protected good, public taxes and duties. Because of the specifics of taxes and duties the offences are not part of the Criminal Code (Strafgesetzbuch-StGB), but are included in the German Fiscal Code (Abgabenordnung-AO). But, tax criminal law follows the criminal law rules and therefore the criminal courts take their own stand on interpretation etc., which means that their point of view can differ from that of the fiscal courts (dealing with the tax issues). ${ }^{1}$

The main offense in tax criminal law is $\S 370$ AO (tax evasion). The offense applies to all taxes and duties as it only speaks of taxes etc. This means, the offense presupposes the details of taxation that are regulated by tax law. In regard to tobacco goods the main legislation is the Tabaksteuergesetz (Tobacco tax law-TabStG).

\footnotetext{
${ }^{1}$ See for such a dispute between criminal and fiscal courts Weidemann (2014), p. 433.
} 
German law makes a difference between the "Verbringung" as the transfer of goods from a EU Member State to Germany and the "Einfuhr" as the import from a third country to Germany. Hence, the illegal transfer of tobacco goods from one EU Member State to Germany (see $\S 23 \mathrm{TabStG}$ ) is to be distinguished from the direct import of tobacco products from a third country into German territory (see $\S$ $21 \mathrm{TabStG})$. Following the distinction made by Art. 15 of the WHO FCTC the reports deals with smuggling, illicit manufacturing and counterfeiting separately. In addition to the in the following mentioned offenses, e.g. § 34 Gesetz über Tabakerzeugnisse und verwandte Erzeugnisse (TabakerzG) as a criminal offense and $\S 35$ TabakErzG as an administrative offense (Ordnungswidrigkeit) cover illegal methods of production and distribution. ${ }^{2}$

\subsubsection{Smuggling}

\subsection{Furnishing Authorities with Incorrect or Incomplete Particulars, $\S$ 370 (1) No. 1 German Fiscal Code (Abgabenordnung: AO)}

For $\S 370$ (1) No. $1 \mathrm{AO}$ it is necessary that taxes are reduced by incorrect statements to the tax authority (or other authorities) upon transfer or import. Anyone who unjustly achieves refunds or the remission of tax claims in terms of the remission and reimbursement procedure regulated in $\S \S 48$ et seq. of the Regulation on the implementation of the Tobacco tax law (Verordnung zur Durchführung des Tabaksteuergesetzes-TabStV), reduces taxes and therefore fulfils $\S 370$ (1) No. $1 \mathrm{AO}^{3}$ The offender who has entrusted the customs formalities to bona fide haulers who have delivered incomplete customs declarations so that no or incorrect import duties have been fixed must be penalized as an indirect offender as of $\S 25$ (I) Alt. 2 StGB. ${ }^{4}$

The most important case of violation of $\S 370$ (1) No. 1 AO occurs, when illicit tobacco products are concealed as regular cargo or camouflaged by other goods without having been declared orderly as stipulated by tax or customs law. If the transferor makes no statements at all, he cannot state anything incorrectly. Thus, he avoids the perpetration of $\$ 370$ (1) No. 1 AO. ${ }^{5}$ However, if he fails to comply with the tax code or makes willingly misleading declarations, he is punishable according to $\S 370$ (1) No. 1 AO.

However, this does not apply to the import of tobacco goods: In the Papismedov judgment, the European Court of Justice ruled that the duty to present goods to customs (Gestellungspflichten) as laid down in Art. 139 (1) Regulation (EU) No

\footnotetext{
${ }^{2}$ For a typical case of organized tobacco trading and applicable offenses see Calderoni et al. (2013), p. 51.

${ }^{3}$ Weidemann and Weidemann (2005), p. 207.

${ }^{4}$ Bundesgerichtshof (BGH), Strafbarkeit des Zigarettenschmuggels (2007) 5 StR 461/06 wistra 2007,262

${ }^{5}$ Instead, § 370 (1) No. 2 AO applies.
} 
952/2013 (Union Customs Code) does not only require the informal notification, that the goods have arrived, but also the declaration of all relevant information which enables the tariff classification and calculation of import duties to be made. ${ }^{6}$ As a result, criminal liability has shifted from the omission of $\S 370$ (1) No. $2 \mathrm{AO}$ to the offence of commission of $\S 370$ (1) No. 1 AO, when illicit tobacco products are not presented to customs. ${ }^{7}$

\subsection{Omission of the Tax Declaration, $\S 370$ (1) No. 2 AO}

Anyone who refrains from declaring taxes in front of the tax authority (other authorities are not mentioned), contrary to an obligation is liable under $\S$ 370 (1) No. 2 AO. The offence of omission is a crime that can only be committed by the tax debtor. ${ }^{8}$ It has to be clarified as to which of those involved in the offence were obliged to submit a corresponding tax declaration. ${ }^{9}$

\section{Transfer to Germany from Another EU Member State: Making the Delivery or} Holding the Tobacco Goods If tobacco goods without the use of German tax marks (see $§ 17$ (1) TabStG) are transferred from the tax-free circulation of another member state to the German tax territory for commercial purposes or if they are sent there, the tax debtor has to submit a tax return on the tobacco goods without delay ( $\S$ 23 para (1) Sentence 1 and (3) TabStG).

According to $\S 23$ (1) Sentence 2 of the Tobacco tax law the person liable for the tax (Erklärungspflichtiger) is the person who makes the delivery or holds the tobacco goods and the recipient as soon as he has acquired possession of the tobacco goods. With regard to the characteristic "who makes the delivery", a certain domination over the goods is required when they are brought to Germany. This is an equivalent to the term "Verbringer" in the customs jurisdiction of the EUCJ. ${ }^{10}$ The decisive criterion in this respect is the domination of the vehicle upon import. Not only the driver has control over the transport vehicle, but possibly (by virtue of their authority to issue instructions) the organizers of the transport as well. At least, if they can rule over the driver in his decision-making before and during the journey, e.g. in terms of route, place and time. ${ }^{11}$ Especially when crossing the green border, criminal

\footnotetext{
${ }^{6}$ Europäischer Gerichtshof (EuGH), Papismedov (2005) C-195/03 Slg 2005, I-1667 31.

${ }^{7}$ Bender (2006), p. 44; Bundesgerichtshof (BGH) Steuerhinterziehung durch Unterlassen (2007) 5 StR 372/06 NJW 2007, 1294.

${ }^{8}$ It is insofar limited to a specific group of persons ("eingeschränktes Jedermannsdelikt"), see Weidemann (2018), p. 13.

${ }^{9}$ Bundesgerichtshof (BGH), Steuerhinterziehung durch Unterlassen (2013) 1 StR 586/12 BGHSt $58,218$.

${ }^{10}$ Bauer (2018), p. 85.

${ }^{11}$ BGH NJW 2007, 1294 (n 7).
} 
liability ${ }^{12}$ depends essentially on the type and manner of import as well as on the type and degree of control over the specific import procedure. ${ }^{13}$

On the one hand, the drivers of the transport vehicles are usually regarded as acting in bad faith because they have imported goods from the third country territory into the customs territory of the European Community bypassing the customs offices. ${ }^{14}$ On the other hand, the question of criminal liability of the indirect perpetrators is not so clear if the goods subject to import duties were imported into the customs territory of the EU by drivers who had no knowledge of the smuggled goods. According to the traditional dogma of omission offences, however, criminal liability for tax evasion as a perpetrator requires that the persons behind the offence themselves had a duty to act. According to the prevailing opinion, the offender of a tax evasion by omission ( $\$ 370$ (1) No. 2 AO) can only be the person who has a special duty to inform the tax authorities. ${ }^{15}$ Insofar, the people behind the transport might only be liable to prosecution by omission as instigators or assistants of tax evasion. $^{16}$

An important extension is that not only the driver, because he drives the vehicle, and his companions in the vehicle have control over the transport vehicle, but by virtue of their authority to issue instructions also those organizers of the transport who have a controlling influence on the driver by taking the decision to carry out the transport and determining the details of the journey (e.g. route, place and time of importation). This has been now clarified in the UCC (see Art. 79 and 139 UCC), ${ }^{17}$ following the jurisdiction of the ECJ. ${ }^{18}$

Import to Germany from a Non-EU Country As a consequence of the Papismedov judgment, the import of tobacco products is not punishable under $\S$ 370 (1) No. 2 AO.

Receiving Tobacco Goods $\S 370$ (1) No. 2 AO applies to the receiver of tobacco goods imported as a tax debtor in terms of $\S 23$ (1) Sentence 2 TabStG. ${ }^{19}$ Yet, The mere participation in the reloading of cigarettes is in any case not sufficient to justify

\footnotetext{
${ }^{12}$ The import duties resulting from irregular introduction pursuant to Art. 79 Union Customs Code were not fixed and thus reduced due to violation of the obligation to present the imported cigarettes (Art. 139 Union Customs Code) resulting in a violation of $\S 370$ (1) No. 2 AO.

${ }^{13}$ BGH NJW 2007, 1294 (n 7).

${ }^{14}$ BGH NJW 2007, 1294 (n 7).

${ }^{15}$ BGHSt 58, 218 (n 9).

${ }^{16}$ Jäger (2015), § 370 AO para. 456.

${ }^{17}$ Art. 38, 40 Council Regulation (EEC) No 2913/92 of 12 October 1992 establishing the Community Customs Code, Official Journal L 302, 19/10/1992, p. 1 were not clear on that point.

${ }^{18}$ See Europäischer Gerichtshof (EuGH) Viluckas \& Jonusas (2004) C-238/02 und C-246/02, C-238/02, C-246/02 Slg 2004, I-2141, 4.3.2004, wistra 2004, 376; see also EuGH-Judgement of 23 September 2004 - C-414/02 "Spedition Ulustrans".

${ }^{19}$ Bundesfinanzhof (BFH) Tabaksteuerschuldnerschaft des Zwischenhändlers (2014) VII R 44/11 BFHE 248, 271.
} 
an obligation to declare taxes as the "recipient" of the tobacco products, ${ }^{20}$ nor can a person who has acquired possession of the tobacco products after the transfer or dispatch process. ${ }^{21}$

\subsection{Omission of the Use of Tax Stamps, $\$ 370$ (1) No. 3 AO}

Those who do not use tax characters in accordance with their obligations are penalized according to $\S 370$ (1) No. 3 AO. The non-use of tax stamps is only punishable if tax stamps are mandatory. ${ }^{22}$ According to $\S 17$ (2) TabStG, only manufacturers, importers and equals are required to obtain tax stamps. Thus, $\S$ 370 (1) No. 3 AO does not apply to the transferor. ${ }^{23}$ Tobacco tax stamps are the only remaining examples of application for this statutory offence. ${ }^{24}$ So, in the event that German tax stamps are not used when untaxed tobacco goods are brought from another EU Member State to Germany for commercial purposes, the importer as the tax debtor of the tobacco tax (cf. $\S 23$ (1) Sentence $2 \mathrm{TabStG}$ ) is a suitable perpetrator of a tax evasion pursuant to $\S 370$ I No. 3 AO. He must ensure that German tax marks are used for the tobacco products when they enter the tax territory of the Federal Republic of Germany.

$\S 370$ (1) No. $3 \mathrm{AO}$ is deemed to have been committed if the tax debtor does not immediately submit a tax return for tobacco products imported without a German tax mark. In such cases, the relationship of the acts of evasion pursuant to $\S 370 \mathrm{I}$ No. $2 \mathrm{AO}$ and $\S 370$ I No. $3 \mathrm{AO}$ is disputed. ${ }^{25}$ But, with regard to the criminal liability associated with the violation of different duties to act, both offences can be committed side by side and do not exclude each other in fact. Hence, the criminal provision of $\S 370$ I No. 3 AO is not merely a catch-all offence which, as a subsidiary offence, takes precedence over the offences of $\S 370$ I No. 1 and $2 \mathrm{AO}^{26}$

\subsection{Illegal Import, Export, or Transit of Goods, § 372 (1) AO}

Criminal liability for illegal import, export, or transit of goods can results from $\S$ 372 AO (so-called "Bannbruch"), if no other specific law criminalizes the behavior.

\footnotetext{
${ }^{20}$ Bundesgerichtshof (BGH) Hinterziehung von Tabaksteuer durch Unterlassen (2015) 1 StR 521/14 wistra 2016, 74.

${ }^{21}$ Bundesgerichtshof (BGH) Erklärungspflicht durch Besitzerwerb (2010) 1 StR 635/09 NStZ 2010,644 .

${ }^{22}$ Weidemann (2018), p. 18.

${ }^{23}$ Weidemann (2018), p. 47, although the issue is disputed, see also Leitner et al. (2017), § $370 \mathrm{AO}$ para. 124.

${ }^{24}$ Weidemann (2017), p. 136. § 370 (1) No. 3 AO was introduced at a time when the TabStG did not contain any declaration obligations and therefore the tobacco tax reduction was not covered by the declaration facts of $\S 370$ (1) No. 1, 2 AO. Insofar the legitimacy of $\S 370$ (1) No. 3 AO has become doubtful, see Weidemann (2017), p. 140.

${ }^{25}$ Weidemann (2017), p. 136.

${ }^{26}$ See for details Jäger (2015), § 370 AO para. 391-395.
} 
The provision is-however-pre-eminently considered irrelevant, ${ }^{27}$ because nowadays, special laws, such as the TabStG, regulate the actions previously covered conclusively, see $\$ 372$ (2) $\mathrm{AO}^{28}$

\subsection{Receiving, Holding or Selling Goods Obtained by Tax Evasion, $\S$ 374 (1) $A O$}

According to $\S 374$ (1) AO it is punishable, among other things, buying, procuring (or helping to procure) himself (or a third party) goods which excise duties or import duties have been evaded, or who sells or helps to sell them with the intention of enrichment. This offense covers the handling of goods that result from tax or custom offenses and follows the same structure as $§ 259$ StGB (Handling stolen goods) in regard to goods that stem from theft offenses.

Transfer to Germany from Another EU Member State If goods are transferred into Germany via another EU member state and not imported, no import duties are payable and consequently no import duties can be evaded. Instead, the transfer tax will be reduced, and-by import into the third country - the import tax on tobacco, which is also a punishable offence under $\S 374$ (4) AO.

Already with the procurement or purchase of cigarettes in other European countries, which were evaded with their import into the customs territory of the EU import duties, the elements of crime of tax fraud are fulfilled. ${ }^{29}$ In order to complete the offence, the elements of "selling" and "sales assistance" presuppose the success of the sale following the case law on $\S 259$ StGB (Handling of stolen goods), as it is considered an Erfolgsdelikt. ${ }^{30}$

The entry into purchase negotiations can be considered as unmittelbares Ansetzen $^{31}$ according to $\S 22$ StGB to tax fraud in the form of "procurement", but only if the transfer can and should follow immediately after agreement on the price. $^{32}$

If it is certain that the import procedure was already completed in the other EU Member State according to the criteria described above. The persons only involved in the onward transport to Germany, in addition to evasion of the German tobacco tax, also carry out the tax fraud pursuant to $\S 374 \mathrm{AO}$ (with regard to import duties). The evasion of import duties in violation of the duty to present goods to customs (Gestellungspflichten) as laid down in Art. 139 (1) Regulation (EU) No 952/2013

\footnotetext{
${ }^{27}$ Küchenhoff (2018), p. 92 f. regards the offense still necessary in cases of the withdrawal of non-EU goods from customs supervision.

${ }^{28}$ See Wegner (2015a), § 372 AO para. 1-3.

${ }^{29}$ Bundesgerichtshof (BGH), Steuerstrafrecht (2008) 1 StR 443/08 wistra 2008, 470.

${ }^{30}$ Weidemann (2018), pp. $74-76$.

${ }^{31}$ The courts accepts an unmittelbares Ansetzen according to $\S 22$ StGB if the (direct) delivery to a third party recipient is agreed, but the planned subsequent handover-even if to be carried out over a long distance-fails because the goods are stolen or confiscated on their way to the recipient.

${ }^{32}$ Bundesgerichtshof (BGH), Steuerhehlerei (2007) 5 StR 371/07 NStZ 2008, 409.
} 
(Union Customs Code) or the evasion of tobacco tax in violation of the obligation to submit a tax return is only completed when the tobacco goods have been brought to safety and have "come to rest". ${ }^{33}$ This is the case when the tobacco goods have crossed the border and the transferor completed his business. ${ }^{34}$

Import into Germany from a Non-EU-State Since $\S 374$ (4) AO refers to the entire section (6) of $\S 370 \mathrm{AO}$, the evasion of domestic excise duties of other member states is also a suitable predicate offence for $\S 374 \mathrm{AO}$. If the goods were not imported but, for example, manufactured in Poland with the consequence that domestic tobacco tax (Polish excise duty) is incurred, this would be a suitable predicate offence for tax evasion, whereas anyone importing untaxed cigarettes into Poland from the Ukraine is liable to prosecution for evasion of customs duties, import turnover tax and Polish import tobacco tax. ${ }^{35}$

\subsubsection{Illicit Manufacturing}

\subsection{Omission of the Tax Declaration, $\$ 370$ (1) No. 2 AO}

$\S 17$ (3) TabStG imposes a tax declaration obligation on the unlawful manufacturer according to $\S 15$ (2) No. 2 and (6), so that in the absence of a declaration only $\S$ 370 (1) No. 2 AO (and not No. 1) must be taken into consideration.

The manufacturer fulfils $\S 370$ (1) No. 2 AO by evading the taxes, provided that the conduct towards the authorities of another member states violated obligations within the meaning of $\S 370$ (1) AO and leads to the presumed tax evasion. The courts have to investigate this, taking into account that obtaining an expert opinion on foreign law is permitted. The courts of fact (Tatsachengerichte) have to differentiate between import and transfer from other Member States: The shortened tax from the predicate offence must be determined correctly because of its importance for the sentence.

If the warehouse keeper fails to oblige to bookkeeping and recording orders issued by the Main Customs Office (Hauptzollamt) in accordance with $\S 10$ (2) Sentence 2 TabStV, he fulfils the omission of $\S 370$ I No. 2 AO. The quasi-causal success in the form of the shortening of the period of assessment exists if the main customs office, if the books had been kept correctly, would have fixed the tobacco tax arising from withdrawal or consumption. ${ }^{36}$

\footnotetext{
${ }^{33}$ Bundesgerichtshof (BGH) Erklärungspflicht durch Besitzerwerb (2010) 1 StR 635/09, NStZ 2010, 644 (n 21).

${ }^{34}$ As a rule of thumb, tax evasion will therefore only be completed once the tobacco goods have reached their destination. If, on the way there, the tobacco products are merely reloaded in an interim storage facility, they have not "come to rest". See Bauer (2018), p. 85.

${ }^{35}$ Weidemann (2018), p. 75.

${ }^{36}$ Weidemann and Weidemann (2005), p. 207.
} 


\subsection{Omission of the Use of Tax Stamps, $\S 370$ (1) No. 3 AO}

Those who do not use tax characters in accordance with their obligations are penalized according to $\S 370$ (1) No. 3 AO. ${ }^{37}$ Following $\S 17$ (2) TabStG, the offence applies to manufacturers, who do not use the previously acquired tax marks in terms of affixing them to the tobacco products they have manufactured, once they are removed from the tax warehouse. ${ }^{38}$

\subsection{Illicit Manufacturing and Distribution of Tobacco Products, $\S$ 34 (1) TabakErzG}

In addition, § 34 (1) TabakErzG criminalizes various ways of producing and distributing tobacco products in violation of the conditions set out in the TabakErzG.

\subsubsection{Counterfeiting}

\subsection{Forgery of Stamps, $\S 369$ (1) No. 3 AO; $148 \mathrm{StGB}$}

If the illicit manufacturer counterfeits tax stamps, he commits forgery of stamps in the sense of $\S \S 369$ (1) No. 3 AO, 148 StGB. The rare offence has seen a new popularity due to German tax stamps which have been counterfeited in Eastern Europe and occasionally found on smuggled cigarette packets. The counterfeits are easily detectable ${ }^{39}$ in forensic laboratories. ${ }^{40}$ The mere preparation of forgery can already be punishable, see $\S 149$ (1) StGB, as well as the attempt to falsify the tax stamp according to $\S 148$ (3) StGB.

\subsection{Punishable Infringement of a Community Trade Mark, § 143a Trade Mark Act}

$\S$ 143a Trade Mark Act (Gesetz über den Schutz von Marken und sonstigen Kennzeichen-MarkenG) punishes the intentional infringement of a Union trade mark and supplements the penal provision applicable to infringement of national trade marks ( $\$ 143$ MarkenG) in this respect. ${ }^{41}$

$\S 143$ a No. 1-3 MarkenG lists possible acts of infringement. § 143a (1) No. 1 MarkenG penalizes the identical use of the Union trade mark for identical goods and services (criminal identity protection). § 143a (1) No. 2 MarkenG makes the use

\footnotetext{
${ }^{37}$ Weidemann (2018), p. 14.

${ }^{38}$ Schmitz and Wulf (2015), § 370 AO para. 352.

${ }^{39}$ The German legislator has just reformed $\S 7$ of the Tabakerzeugnisgesetz in order to require unforgeable stamps to be applied to tobacco products, see Erstes Gesetz zur Änderung des Tabakerzeugnisgesetzes of 29. April 2019, BGB1. I p. 514. See also BT-Drs. 19/4461.

${ }^{40}$ Harder (2014), Chapter 22 para. 106.

${ }^{41}$ Kutschke (2018), § 143a MarkenG para. 1 ff.
} 
of signs identical with or similar to the Union trade mark for identical or similar goods punishable if this creates a likelihood of confusion on the part of the public (criminal protection against confusion); however, uses of a trade mark which is identical with or similar to an established mark in the Union for identical or similar goods or services are not sanctioned by $\S 143 \mathrm{a}(1)$ No. 1-3 MarkenG, but covered by civil law. ${ }^{42} \S 143 \mathrm{a}$ (1) MarkenG also presupposes that the offender has used the Union trade mark despite a prohibition. The absolute prohibition of the use of the Union trademark, is a consequence of its publication. ${ }^{43}$ Criminal liability is limited to the use in commercial transactions with the pursuit of a business purpose.

The reference in $\S 143 \mathrm{a}$ (2) MarkenG to $§ 143$ (2) MarkenG ensures that the scope of criminal protection of the Union trade mark corresponds in all other respects to that of the national trade mark. Thus, the reference to § 143 (2) MarkenG increases the penalty for a commercial or gang offence. Moreover, the punishability of the attempt is given by the reference to $\S 143$ (3) MarkenG. As can be seen from the reference to $\S 143$ (4), the infringement of a Union trade mark is in principle only prosecuted upon a request to prosecute, unless the prosecution authority considers that there is a special public interest. In addition, due to the reference $\S$ 143 (5) MarkenG goods in question can be confiscated. Also, the publication of the conviction can be ordered in the case of a conviction, see $§ 143$ (6) MarkenG.

\subsubsection{Administrative Offenses}

Besides the aforementioned criminal offenses a large number of administrative offenses (Ordnungswidrigkeiten) exist in regard to the evasion of taxes and other fiscal duties. These offenses are mainly regulated either in $\S \S 377-384 \mathrm{a} \mathrm{AO}$ or in the TabStG and the TabStV. The offenses follow the general rules set out in the Ordnungswidrigkeitengesetz (OWiG) that are comparable to the criminal law standards. The main administrative tax offense is $\S 378 \mathrm{AO}$, the reckless understatement of tax. The offense requires as actus reus the same elements of crime as $\S 370 \mathrm{AO}$ but as mens rea element negligence in the form of recklessness is sufficient. Insofar intent makes the behavior a crime under $\S 370 \mathrm{AO}$, recklessness an administrative offense under $\S 378 \mathrm{AO}$.

$\S 379$ AO covers general minor tax fraud, especially using or producing incorrect documents, making incorrect statements or not timely providing notifications or reports. $\S 380$ covers failing to comply at all, in full or in time with an obligation to withhold or remit to revenue authorities tax amounts which are due. § 381 AO sanctions the endangerment of excise taxes in combination with other regulations that require a specific behavior. Such regulations are $\S 36 \mathrm{TabStG}$ and $\S 60 \mathrm{TabStV}$ in the field of tobacco trading. They cover a wide range of formal requirements, e.g. in regard to documentation, presentation and notification.

\footnotetext{
${ }^{42}$ See Art. 9 (2) lit. c of Regulation (EU) No. 1001/2017.

${ }^{43}$ Fezer (2009), § 143a MarkenG para. 6.
} 
In addition, specific provisions sanction further behavior. Among these is $\S$ $37 \mathrm{TabStG}$ that criminalizes the purchase of cigarettes without a valid tax stamp insofar as not more than 1000 cigarettes are concerned. This regulation privileges the purchase of small amounts, it also declares $\S \S 369-374$ AO inapplicable. Moreover, anyone who is unable to rebut the assumption that illegal goods or equipment in terms of $\S 12 \mathrm{e}$ (1) Sentence 1 Zollverwaltungsgesetz (ZollVG) are carried in crossborder traffic with the intention of committing a tax offence under $\S 369 \mathrm{AO}$, can be fined according to $\S 31 \mathrm{a}$ (1) No. 5 ZollVG.

\subsubsection{Fiscal Responsibility for Illicit Trade}

\subsubsection{Smuggling}

\subsection{Transfer}

For cigarettes, which have been imported or manufactured illegally in another member state of the EU and subsequently introduced into German tax territory, the following taxes and duties are imposed:

- the German tobacco tax as excise duty for transfer ( $§ 23 \mathrm{TabStG})$,

- duties already levied by the other EU member state.

\subsection{Import}

When importing goods into Germany from non-EU-countries the following taxes arise:

- the German tobacco tax as excise duty for import ( $\$ 21 \mathrm{TabStG})$,

- customs duties in accordance with the regulations of the European Union, and

- the national import turnover tax. ${ }^{44}$

\subsection{Description of the Taxes}

Tobacco Tax: General The German tobacco tax is collected, if either $\S 21 \mathrm{TabStG}$ (Import) or $\S 23 \mathrm{TabStG}$ (Transfer) is fulfilled. The calculation of the German tobacco tax is determined in accordance with $\S 2 \mathrm{TabStG}$ irrespective of whether the tobacco tax is levied directly in Germany similar to an import tax or when smuggled in or only when brought into the German tax territory from another member state of the EU. In order to calculate the tobacco tax, it is necessary to calculate the so-called retail selling price, i.e. the price determined by the manufacturer or importer as the retail price for cigarettes per unit $(\S 3$ (1) TabStG). If there is no regular legal retail selling price based on taxed cigarettes in Germany, it has to be

\footnotetext{
${ }^{44}$ Jäger (2009), p. 452.
} 
estimated on the basis of the average retail selling price of branded cigarettes in the lower price segment. ${ }^{45}$ The (possible) black market price is not to be used, as this would unfairly favor the smugglers. ${ }^{46}$

Tobacco Tax: $\$ 23$ TabStG (Transfer) If tobacco products, to which no German tax stamps are attached, ${ }^{47}$ are brought into the German tax territory or dispatched for commercial purposes from the tax-free free circulation of another EU member state, the tobacco tax arises when the tobacco products are held in Germany for the first time for commercial purposes ( $\$ 23$ (1) Sentence 1 TabStG). Pursuant to $\S 23$ (1) Sentence $2 \mathrm{TabStG}$, the tax debtor is a person who conducts the delivery or holds the tobacco goods in possession as well as the recipient as soon as he has acquired possession of the tobacco goods. The tax debtor has to submit a tax return immediately in accordance with $\S 23$ (1) Sentence 3 TabStG in conjunction with $\S$ 17 (1) TabStG. ${ }^{48}$ The requirement for immediate action demands the visit of the nearest main customs office as the competent tax authority ( $\$ 6(2)$ No. 5 AO) and that a tax return be submitted there. ${ }^{49}$ It is not necessary for the transferor to be aware of the existence of excise goods. ${ }^{50}$

The transferor has no choice as to whether he uses tax stamps or whether he declares the tobacco tax to the customs authorities immediately after the transfer. If he does not want to be criminally liable under $\$ 370$ (1) No. 3 AO, he must use tax stamps before bringing the tobacco goods to Germany. For the registration in the case of $\S 23$ (1) Sentence $3 \mathrm{TabStG}$ does not serve to clear the tobacco goods for free circulation; it is intended solely to guarantee the levying of the tobacco tax incurred pursuant to $\S 23$ (1) Sentence 2 TabStG as well as, if tobacco goods are not properly released for free circulation, the securing $(\$ 215 \mathrm{AO})$ and the confiscation of the tobacco goods ( $\$ 375$ II AO). ${ }^{51}$

If the goods cross the German border, the offence of tax evasion with regard to the German tobacco tax (excise duty) pursuant to $\S 370$ (1) No. 2 AO in conjunction with $\S 23$ (1) Sentence 3 TabStG will also be realized if the goods are brought tax-free into the Federal Republic of Germany from another EU member state without the corresponding tax mark.

With regard to the characteristic "who conducts the delivery", a certain domination over the goods is required when they are brought to Germany. The decisive sign

\footnotetext{
${ }^{45}$ Bauer (2018), p. 88.

${ }^{46}$ Bundesgerichtshof (BGH) Steuerhinterziehung (2004) 5 StR 554/03, wistra 2004, 348.

${ }^{47} \S 23$ TabStG does not cover tobacco products bearing German tax stamps, for example because a manufacturer authorized to obtain tax stamps in accordance with $\S 17$ (2) TabStG is a consignor and has used the tax stamps.

${ }^{48}$ Bundesgerichtshof (BGH) Strafverfahren wegen Steuerhinterziehung (2014) 1 StR 240/14, wistra $2014,486$.

${ }^{49}$ Jäger (2015), § 370 AO para. 386.

${ }^{50}$ Bundesfinanzhof (BFH) Tabaksteuerschuldnerschaft für versteckte Waren (2007) VII R 49/06, BFHE 218, 469.

${ }^{51}$ Jäger (2015), § 370 AO para. 390.
} 
in this respect is the domination of the vehicle upon import. As mentioned, not only the driver has control over the transport vehicle, but also the organizers of the transport by their authority to issue instructions who have control over the driver by making the decision to carry out the transport and determine the details of the journey (e.g. route, place and time of import). Yet, again, the mere participation in the reloading of cigarettes is not sufficient to justify an obligation to declare taxes as the "recipient" of the tobacco products.

For private purposes, the transfer by private individuals is tax-free according to $\S$ 22 (1) TabStG, provided it is for their own use (i.e. not for other persons, not even as a gift) and the goods are transferred to the tax territory by the recipient himself (not, for example, by other persons or by mail). The quantities are determined according to $\S 39$ TabStV (currently 800 pieces for cigarettes). Excessive quantities are assumed to have been transferred on a commercial basis. For tax purposes, this is to be understood as a legal fiction (unlike the provision in $\S 22$ (4) TabStG, which speaks of a rebuttable presumption).

Also, a "private individual" can easily become a commercial transferor simply by bringing tobacco goods with him for third parties. In such cases, there will often be an error about "the tax claim", as the common opinion is that there is free movement of goods within the EU. ${ }^{52}$ Since, furthermore, according to $§ 1$ (2) ZollVG, customs must also monitor the movement of excise goods across the internal border, $\S$ 32 (1) ZollVG (Non-Prosecution of Trifles under $250 €$ ) must be applied mutatis mutandis in this context, insofar as the transfer is not duty-free. The distinction from commercial use is made by taking into account the "criteria" mentioned in $\S$ 22 (2) No. 1-4 TabStG. For certain quantities, a (rebuttable) presumption of commercial use exists for tax purposes. In criminal proceedings, however, commercial use must be proven to the satisfaction of the court for the conviction. ${ }^{53}$ Any person who holds the tobacco products for commercial purposes, even if he was not the first owner in the Member State of destination, is to be regarded as the owner. ${ }^{54}$

Tobacco Tax: $\$ 21$ TabStG (Import) The tax debtor is the person required under customs legislation to declare the tobacco products or on whose behalf the tobacco products are declared or any other person involved in an illegal import (\$ 21 (2) Sentence $1 \mathrm{TabStG}$ ). This concerns the person who has control over the transfer, either as the transferor or the recipient of the goods. ${ }^{55}$ If tobacco products are imported into the territory of the EU and are transported through several member states, the state's right of collection ends as soon as the goods leave its territory. ${ }^{56}$ This does not alter the punishment for tax evasion by omission according to $\S 370$ (1) No. 2 AO, if a tax

\footnotetext{
${ }^{52}$ Weidemann (2018), p. 41.

${ }^{53}$ Weidemann (2018), p. 41.

${ }^{54}$ BFHE 248, 271 (n 19); Europäischer Gerichtshof (EuGH) Gross (2014) C-165/13, wistra $2014,433$.

${ }^{55}$ BGH, NJW 2007, 1294 (n 7); EuGH, wistra 2004, 376 (n 18).

${ }^{56} \mathrm{BGH}$, wistra 2016, 74 (n 20).
} 
return is not submitted immediately after crossing the German border, $§ 23$ (1) Sentence 3 TabStG. ${ }^{57}$

Taxes by Other Member States There are particular difficulties when it comes to penalizing the evasion of national turnover and tobacco tax from another member state. The foreign legal situation must be clarified ex officio, making a foreign legal advisory opinion necessary on a regular basis. In cases where the determination of the foreign duties is too complicated, prosecution in respect to the reduced duties may be limited pursuant to $\S \S 154,154$ a Code of Criminal Procedure (Strafprozessordnung-StPO) to customs evaded upon importation into another Member State and/or German tobacco tax evaded upon introduction into the German excise territory. ${ }^{58}$ This is intended to save the courts from having to make difficult findings about foreign tobacco tax law. ${ }^{59}$ Insofar, goods should not be subject to the excise duties of several Member States. This is also the principle underlying the possibility of refunding excise duty levied in other Member States. ${ }^{60}$ Furthermore, any (even "neutral") help carried out in Germany to acts in other EU countries is punishable by law. ${ }^{61}$

Import Tax In the case of cigarette smuggling, the incurrence of a customs debt is governed by Article 79 (1) of Regulation (EU) No 952/2013 (Union Customs Code-UCC) by unlawful introduction, i.e. the disregard of the customs regulations applicable to the registration of goods. This implies

- breaches of transport obligations under Art. 135 (1), (2) Union Customs Code;

- failure to present goods contrary to Art. 139 Union Customs Code;

- no or insufficient applications for temporary storage of goods contrary to Art. 145 Union Customs Code. ${ }^{62}$

For the calculation of the customs debt, the customs value is the relevant starting point. The customs value for imported goods is generally determined in accordance with Art. 70 UCC according to the so-called transaction value, i.e. according to the price actually paid or payable for the imported goods in the case of a sale for export to the customs territory of the Community, or after adjustment in accordance with Art. 71, 72 UCC. The transaction value is therefore generally determined by the gross settlement price to be paid or already paid to the seller. It does not matter whether the agreed sum is to be paid directly to the seller or indirectly by payment to a third party. If the customs value cannot be determined according to Art. 70 UCC or according to the alternative methods according to Art. $74(1,2) \mathrm{UCC}$, it must be

\footnotetext{
${ }^{57}$ Weidemann (2018), p. 48.

${ }^{58}$ BGH NStZ 2010, 644 (n 21).

${ }^{59}$ Weidemann (2018), p. 48.

${ }^{60}$ BGH NStZ 2010, 644 (n 21).

${ }^{61} \mathrm{BGH}$ (Bundesgerichtshof) Neutrale Beihilfe zur Steuerhinterziehung in Polen (2017) 1 StR 56/17, NStZ 2018, 328.

${ }^{62}$ Europäischer Gerichtshof (EuGH), Papismedov (2005) C-195/03 Slg 2005, I-1667 31.
} 
determined on the basis of Art. 74 (3) UCC (so-called final method). In his reasoning the judge must state whether and, if so, on what basis he has made an estimate of the tax base. If no valuation bases are available for the imported cigarettes, the estimate to be made can in turn be based on the usual import price for branded cigarettes in the lower price segment. The resulting customs value must finally be multiplied by the customs rate in order to determine the specific customs debt. ${ }^{63}$

In the event of a breach of duty relating to the introduction, the person liable to pay customs duty under Article 79(3)(a) UCC is the person who had the obligation to bring the goods properly into the customs territory:

- Transferor, i.e. the actual carrier: The customs obligation of the transferor may be transferred to another person after introduction into the customs territory of the Union. If it turns out that, contrary to Art. $135 \mathrm{UCC}$, the goods were transported after the introduction, the person liable for customs duty is the person who was responsible for the transport at the relevant time. If it is not clear who was responsible at the time of the breach of duty, it is to be assumed that this is the transferor. ${ }^{64}$

- Representative: Pursuant to Article 79(3)(b) UCC, the representative also becomes a customs debtor.

- Other persons involved in the unlawful removal (e.g. co-drivers, participants or helpers): Any person who initiates or supports the breach of duty through his or her conduct is generally involved in the breach of duty. This can be done, for example, by giving the actor appropriate instructions or assistance for his actions. Personal presence is not required. ${ }^{65}$ This also applies to anyone who provides storehouses where the goods can be unloaded from the means of transport used for the irregular introduction, provided that this was already clear beforehand (prior promise of a later use). ${ }^{66}$

- Owner or acquirer of the goods: Finally, a person who acquired the goods by legal transaction after the transfer and thus after the customs debt was incurred (purchase is sufficient) or acquired possession of the goods otherwise (directly or indirectly) is a customs debtor. The "consignee" is the person who receives untaxed tobacco products in the tax territory by establishing his actual dominion (sovereignty) over them. ${ }^{67}$ The purpose of determining the person liable for the payment of the excise duty is to be able to claim the benefit of the person in whose immediate custody a product subject to excise duty is located and who can therefore be easily identified on the basis of objective circumstances and made liable for paying taxes. ${ }^{68}$

\footnotetext{
${ }^{63}$ Bauer (2018), p. 88.

${ }^{64}$ Zoll (2019).

${ }^{65}$ Europäischer Gerichtshof (EuGH) Spedition Ulustrans (2004) C-414/02, Slg 2004, I-8633.

${ }^{66}$ Bundesfinanzhof (BFH) Beteiligung am Verbringen (2006) VII R 24/04, BFHE 213, 473.

${ }^{67}$ Bundesfinanzhof (BFH) Steuerschuldnerschaft als Empfänger (2012) VII R 50/11, BFHE 237, 554.

${ }^{68}$ Müller (2018), p. 2667.
} 
It is irrelevant whether the transferring person knew of the irregular conduct. However, it is a prerequisite for the customs debt of the representative, participant and the owner or acquirer of the goods, that they know or should reasonably have known about the breach of duty. In this respect, the point of view of the informed and carefully acting economic operator is decisive. ${ }^{69}$ The act is completed as soon as the goods have crossed the EU external border in violation of the duty to present goods to customs (Gestellungspflichten) as laid down in Art. 139 (1) UCC.

No customs debt is incurred on importation and therefore no punishment for tax evasion can be meted out if it is unclear whether the cigarettes were brought into the customs territory of the Union or manufactured in the territory of a Member State. ${ }^{70}$ Consequently, no import duties arise on counterfeited cigarettes which may also have been manufactured in the customs territory of the Union. The burden of ascertaining that goods have been brought into the customs territory of the Union in contravention of the regulations is with the tax authority. ${ }^{71}$

According to Art. $87(1,2)$ UCC, the customs debt is incurred where the customs offence is fulfilled, i.e. when goods are imported from outside a Member State. Art. 87 (4) UCC contains an exception for smaller amounts (customs debt under 10.000 $€)$ : The customs debt is "deemed" to have arisen where it is established, i.e., if the customs authorities establish that a customs debt has arisen in another member state, the place of origin is deemed to be the place where it was established. This legal fiction serves to facilitate collection and is therefore a rule for establishing the jurisdiction for the customs administration of the Member State in which the customs debt was incurred. This rule does not apply to excise duties and import turnover tax. $^{72}$

National Import Turnover Tax, § 21 UStG The provisions for customs duties apply mutatis mutandis to import turnover tax $(\$ \S 21$ (2) Value Added Tax ActUmsatzsteuergesetz-UStG). The (German) import turnover tax is calculated by multiplying the relevant tax base by the German tax rate $(19 \%) .^{73}$ If cigarettes smuggled into the customs territory of the Union and seized in Germany were brought into the German tax territory via a particular other Member State, the German customs administration shall, in addition to the customs duty and the tobacco tax applicable to the tobacco goods, also determine the import turnover tax if the customs debt is less than $€ 5,000 .{ }^{74}$ In that case, the import turnover tax arises after the tobacco products have been unlawfully brought into the German tax

\footnotetext{
${ }^{69}$ Europäischer Gerichtshof (EuGH) Jestel (2011) C-454/10, Slg 2011, I-11725 ().

${ }^{70}$ FG Hamburg Einfuhrabgaben bei gefälschten Zigaretten (2017) 4 K 217/16.

${ }^{71}$ Weidemann (2018), p. 55.

${ }^{72}$ Deimel (2019), Art. 87 UZK para. 18.

${ }^{73}$ Bauer (2018), p. 88.

${ }^{74}$ BFHE 237, 554 (n 67).
} 
territory, so that the resulting tobacco tax must be added to the basis of assessment for the import turnover tax. ${ }^{75}$

\subsubsection{Illicit Manufacturing}

\subsection{Furnishing Authorities with Incorrect or Incomplete Particulars, $\S$ 370 (1) No. 1 AO}

According to $\S 10$ (2) and (3) TabStV the warehouse keeper has to keep a stock book in which he has to record the entries and exits. If he keeps the books incorrectly and submits these records to the main customs office, he fulfils the elements of crime of $\S$ 370 I No. 1 AO by providing incorrect information. ${ }^{76}$

\subsection{Omission of the Use of Tax Stamps, $\$ 370$ (1) No. 3 AO}

The non-use of tax stamps is only punishable if tax stamps are mandatory. ${ }^{77}$ Tobacco tax must be paid using tax stamps by invalidating and affixing them to the retail sales packages (at the latest) at the time the tax arises ( $\$ 17$ (1) TabStG). ${ }^{78}$ According to $\S$ 17 (2) TabStG, manufacturers, importers and equals are entitled to obtain tax stamps from the main customs office in Bielefeld ( $\$ 32$ (1) TabStV).

The main purpose for the use of tax stamps lies in their publicity effect. They must therefore already be used before the tax arises, i.e. before they are released into free circulation, even if they only then develop their tax effect. ${ }^{79}$ At the time of tax emergence, the tobacco tax claim is met immediately within one logical second with the consequence of extinction. Illicit tobacco products, for which no tax stamps have been used are "taxed" even if they have been subject to tax evasion, because the use of tax stamps concerns only the collection of tobacco tax.

The tax arises when tobacco products are released for consumption, unless it is followed by a tax exemption ( $\$ 15$ (1) of the TabStG). If the tobacco tax arises, the tax mark must be affixed ( $\$ 17$ (1) Sentence 3 TabStG). Tobacco products are released for free circulation through

- withdrawal from a tax warehouse, unless followed by another procedure of tax suspension (consumption in the tax warehouse is equivalent to withdrawal, $\S$ 15 (2) No. 1 TabStG);

- production without permission according to $\S 6$ TabStG (§ 15 (2) No. 2 TabStG);

- an irregularity under $\S 14$ TabStG during carriage under suspension of excise duty ( $\$ 15$ (2) No. 4 TabStG).

\footnotetext{
${ }^{75}$ BFHE 237, 554 (n 67).

${ }^{76}$ Weidemann and Weidemann (2005), p. 207.

${ }^{77}$ Weidemann (2018), p. $30 \mathrm{f}$.

${ }^{78}$ Jäger (2015), § 370 AO para. 377.

${ }^{79}$ Jäger (2015), § $370 \mathrm{AO}$ para. 378.
} 
Tobacco products from other EU member states may be obtained from registered consignees under tax suspension ( $\S 12$ (1) No. 2 lit. b, 7 TabStG). The tobacco tax then arises when the tobacco is withdrawn from the procedure under tax suspension when it is admitted into the business of the registered recipient ( $\$ 15$ II No. 3 TabStG). At this time, the tax characters must be used ( $\$ 17$ I 3 TabStG). ${ }^{80}$

\subsubsection{Relation Between Criminal and Administrative/Fiscal Responsibility}

Under German law fiscal responsibilities to pay taxes and duties exist besides any criminal or administrative liability. In case of tax evasion this means that taxes and duties that apply must be paid following taxation rules. In addition, criminal and/or administrative sanctions can apply. This means taxation and criminal/administrative sanctions are seen as different measures so that no "ne bis in idem principle" applies. In regard to the relationship between criminal and administrative offences, criminal liability prevails if offenses cover the same conduct (see $\S$ 21 Ordnungswidrigkeitengesetz-OWiG).

There is a mandatory procedural obstacle according to $\S 32$ ZollVG for tax offences under $\S 369 \mathrm{AO}$ (and also tax administrative offenses under $\S 377 \mathrm{AO}$ ) in cross-border travel (i.e. no illegal border crossing and no connection with commercial traffic in goods are covered. ${ }^{81}$ This requires that the reduction in import, export or excise duties attributable to goods in excess of the duty-free quantity ${ }^{82}$ does not exceed $250 €$ in total.

\subsection{Relations Between Criminalization of Illicit Trade of Tobacco and Other Types of Economic Crimes}

Illicit trade of tobacco often goes along with money laundering pursuant to $\S$ 261 StGB and forgery of stamps in the sense of $\S \S 369$ (1) No. 3 AO; 148 StGB. ${ }^{83}$ The provision on money laundering in $\S 261$ StGB plays a particular important role, because it permits the prosecution of those who have participated in the deferral and distribution of the illegally obtained proceeds, such as the managing directors of fictitious companies or the relatives of the smugglers. ${ }^{84}$ Additionally, organized smuggler gangs can be regarded as criminal associations according to $\S$

\footnotetext{
${ }^{80}$ Jäger (2015), § 370 AO para. 379.

${ }^{81}$ Harder (2014), Chapter 22 para. 111-112.

${ }^{82}$ BayObLG Hinterziehung von Zollabgaben (2000) 4St RR 98/2000, 4St RR 98/00, BayObLGSt 2000, 121.

${ }^{83}$ Knickmeier (2016), p. 431.

${ }^{84}$ Koziolek (2015a), p. 215.
} 
$129 \mathrm{StGB}^{85}$ Even though the reasoning is usually difficult and the requirements of the jurisdiction are high, $\S 129$ StGB served as a justification for the implementation of surveillance measures against smuggling gangs until $§ 100 \mathrm{a}$ (2) No. 2 StPO was amended in $2008 .^{86}$

Also, there is a liability for assistance after the fact. According to $\S \S 369$ (1) No. $4 \mathrm{AO} ; 257 \mathrm{StGB}$ (Assistance after the fact) it is punishable to assist the offender of an unlawfully committed tax offence as of $\S 369$ (1) No. 1-3 AO in order to secure the benefits he has obtained from such a tax offence. In practice, advantages within the meaning of the preferential treatment lie in the occurring reduction of taxes. ${ }^{87}$ In the case of tax evasion, the benefit is complete if the assistance provided makes it impossible to enforce the tax claim or at least makes it even more difficult than it has already been due to the evasion. ${ }^{88}$ In this sense, the prevailing opinion is that the offence must be objectively suitable and subjectively intended to secure the advantages of the tax offence committed against confiscation for the offender. ${ }^{89}$

In most cases the illicit trade of tobacco does not fulfill the elements of fraud ( $\S$ $263 \mathrm{StGB}$ ) as this requires deceiving someone who then acts because of an error and creates some damage based on the deception. Although tobacco companies suffer some damage if falsified products with their name or logo etc. are sold, ${ }^{90}$ often there is no deception of the consumer or an error on side of the consumer.

\subsection{Aggravating Cases of Illicit Trade of Tobacco Products}

\subsubsection{Professional, Violent or Organized Smuggling, § 373 AO}

Anyone who evades import or export duties on a commercial basis or who illegally imports, exports or transports goods on a commercial basis in contravention of monopoly regulations on a commercial basis shall be punished under the aggravated offense of $\S 373$ (1) AO, providing to a sentence of at least 6 months of imprisonment up to 10 years of imprisonment. This also applies to any person who

- evades import or export duties or illegally imports, exports or transports goods, and in committing these acts he or another participant carries a firearm ( $\S$ 373 (2) No. 1 AO),

\footnotetext{
${ }^{85}$ Koziolek (2015a), p. 215.

${ }^{86}$ Bauer (2018), p. 87.

${ }^{87}$ Bundesgerichtshof (BGH) Begünstigung bei Steuerhinterziehung (1998) 5 StR 746/97, wistra 1999, 103; Jäger (2000), pp. 346-347.

${ }^{88}$ Bundesgerichtshof (BGH) Begünstigung bei Steuerhinterziehung (n 87); Beihilfe zur Steuerhinterziehung (2000) 5 StR 624/99, BGHSt 46, 107.

${ }^{89}$ BGHSt 46, 107 (n 88).

${ }^{90}$ Hefendehl (2015) § 263 StGB para. 493.
} 
- evades import or export duties or illegally imports, exports or transports goods, and in committing these acts he or another participant carries with him a weapon or some other tool or means to prevent or overcome the resistance of another person by violence or by the threat of violence ( $\$ 373$ (2) No. 2 AO), or

- as a member of a group formed for the purpose of repeatedly evading import or export duties or of illegally importing, exporting or transporting goods, commits such an act (§ 373 (2) No. 3 AO).

$\S 373 \mathrm{AO}$ is applicable instead of $\S 370 \mathrm{AO}$ as a qualifying offence in the case of a reduction of import duties, but not in cases of a reduction of taxes arising within the country or from transfers from other member states. The offence is deemed to have been committed when tobacco products (under the abovementioned qualification) are moved from a third country to the EU without presentation. In contrast to $\S$ 370 (6) sentence 1 and $\S 374$ (2) AO, import duties administered by another Member State of the European Union are not covered by the facts of $\S 373$ AO. Therefore, import duties within the meaning of $\S 373$ AO are only the customs duties administered by Germany for the $\mathrm{EU}^{91}$ as well as German import turnover tax and tobacco tax. It must be observed that only in cases in which tobacco products are imported directly from a non-EU-country into Germany (e.g. by air or via a free port such as Hamburg and Bremerhaven) the German tobacco tax arises with the import turnover tax and the customs duty as import duty (cf. § 53 (3) AO). Accordingly, § 373 AO does not cover the German tobacco tax as import duty if the cigarettes are not brought directly from a non-member state of the European Union to Germany. ${ }^{92}$

$\S 373 \mathrm{AO}$ is therefore only relevant if the goods are transported directly to Germany from outside the EU. The import duties, customs duty, import turnover tax, import tobacco tax (but not, for example, domestic tobacco tax) are then reduced. If, on the other hand, the goods are initially moved from the third country to another Member State and from there to Germany, the import duties are reduced when the goods cross the EU external border and the German border, the transfer tobacco tax. In this case both measures constitute a criminal offense.

If, e.g., cigarettes originating from Asia are transported by ship to Germany hidden under goods to be cleared and imported via the free ports, this constitutes commercial and gang smuggling in the sense of $\S 373$ (1), (2) No. 3 AO in conjunction with $\S 370$ (1) No. 1 AO. ${ }^{93}$

It is important that the criminal court judge considers the legal qualification that both commercial conduct ( $\$ 373$ (1) AO) and gang membership ( $\$ 373$ (2) No. 3 AO) are special personal characteristics within the meaning of $\S 28$ (2) StGB with

\footnotetext{
${ }^{91}$ Bender (2001), p. 166; BGH (Bundesgerichtshof) Hinterziehung von Eingangsabgaben (1987) 3 StR 146/87, ZfZ 1987, 345.

${ }^{92} \mathrm{BGH}, \mathrm{NJW} 2007,1294$ (n 7). When the transport (e.g. by land) into the German territory takes place via another EU member state, Tatmehrheit ( $\$ 53 \mathrm{StGB}$ ) between $\S 373 \mathrm{AO}$ (related to the import duties administered by the EU member state) and $\S 370$ Paragraph 1 No. $2 \mathrm{AO}$ (related to the German tobacco tax) must be assumed, cf. Bauer (2018), p. 85.

${ }^{93}$ BGH wistra 2007, 262 (n 4).
} 
the consequence that a party to the offence who does not possess the personal characteristics can only be punished for participating in the basic offence ( $\S$ $370 \mathrm{AO})$.

\subsection{2 $\$ 370(3) \mathrm{AO}$}

In $\S 370$ (3) AO the law provides for aggravating cases of tax evasion mentioned in $\S$ 370 (1) AO. The nature of these "Strafzumessungsregeln" (sentencing rules) only affects the applicable sentence but does not change the nature of the offense (so that the cases that are covered do not qualify as a qualified offense). ${ }^{94}$ If the criteria of $\S$ 370 (3) $\mathrm{AO}$ are met, in general the higher sentencing range of imprisonment from 6 months to 10 years applies. Yet, if there is a non-average case, the rules do not have to be applied. Insofar, the judge has some discretion to apply the higher sentencing range or not. The most important constellations under $\S 370$ (3) AO are:

- tax evasion on a large scale (No. 1), whereas the courts regard evaded taxes or import duties etc. of at least 50.000 EUR to be large scale, ${ }^{95}$

- abuse of the authority or position as a public official (No. 2) and making use of this abuse (No. 3) ${ }^{96}$

- repeated use of falsified or forged documents (No. 4);

- commission of the offense as a gang member (No. 5). ${ }^{97}$

If a case falls under $\S 370$ (3) AO a special limitation period of 10 years applies (see $\S 376 \mathrm{AO}$ ), whereas for a normal case under $\S 370$ (1) AO the normal limitation period of 5 years (see $\S 78 \mathrm{StGB}$ ) applies. ${ }^{98}$

\subsection{Legal Responsibility of Individuals for Illicit Trade of Tobacco Products}

The main responsibility for the trade in tobacco products is of an administrative nature. Especially the "Gesetz über Tabakerzeugnisse und verwandte Erzeugnisse (TabakerzG)" and the "Verordnung über Tabakerzeugnisse und verwandte Erzeugnisse (TabakerzV)" set out the basic framework how to deal with tobacco products. In addition, the trading of tobacco products is an important fiscal issue so that the TabStG and the TabStV provide for further obligations. These obligations have to be observed independent of any specific state of mind of the person affected.

\footnotetext{
${ }^{94}$ Hadamitzky and Senge (2018), § 370 AO para. 87.

${ }^{95}$ Hadamitzky and Senge (2018), § 370 AO para. 88.

${ }^{96}$ Hadamitzky and Senge (2018), § 370 AO para. 90b; see also Jäger (2015), § 370 AO para. 577.

${ }^{97}$ Jäger (2015), § 370 AO para. 579-584.

${ }^{98}$ Budde (2019), p. 28.
} 
If obligations are not observed the public authorities have the power to enforce them in administrative or fiscal proceedings.

In addition, the breach of main obligations is sanctioned in the respective legislation either as a criminal or (if regarded less important) as an administrative offense. In these cases individual responsibility requires the existence of a subjective element, especially intention or negligence. Important criminal offenses such as $\S \S$ $370,372,373,374 \mathrm{AO}$ require intent. Nonetheless they cover a large number of criminal behavior as they regulate conduct prior to the commission of fraud offenses and insofar are "Vorfeldtatbestände". In contrast administrative offenses can often be committed intentionally and negligently, although in the majority of administrative tax offenses a special form of negligence is needed, the so-called "Leichtfertigkeit". 99 Normal negligence is not sufficient, there must be a higher degree of guilt. ${ }^{100}$ It is comparable to the Anglo-American concept of recklessness.

\subsection{Sanctions Applicable for Illicit Trade of Tobacco Products (Individuals)}

\subsubsection{Taxes}

Any person who evades taxes or receives, holds or sells goods obtained by tax evasion or participates in such an act is liable for the taxes understated or the tax advantages wrongfully granted ( $\$ 71 \mathrm{AO})$. Also, interest has to be paid on evaded taxes ( $\S 235,238 \mathrm{AO})$. These payments are not regarded as sanctions as they are only intended to reimburse the state for the damage caused.

\subsubsection{Criminal Sanctions}

As criminal sanctions for criminal offenses fines and imprisonment apply, depending on the offense committed. Fines are determined by the general rules in $\S \S 40,41$ StGB. They are calculated by multiplying the number of daily units (ranging from 5 to 360 depending on individual guilt) with the daily amount (from 1 to 30,000 EUR depending on the individual income). The maximum term of imprisonment depends on the offense committed. Often these offenses provide for a maximum sentence of 5 years of imprisonment such as the main tax crimes in $\S \S 370,372$, 374 AO. In addition to at least 1 year's imprisonment $\S 375$ (1) AO provides in regard to the most important tax offenses for the possibility to disqualify someone from holding public office and acquiring rights from public elections.

\footnotetext{
${ }^{99}$ Heuel (2016), § 378 AO para. 54 ff.

${ }^{100}$ See BGH of 29.4.1959—2 StR 123/59, DStZ/B 1959, 351 (352).
} 


\subsubsection{Forfeiture}

In cases of criminal offenses the forfeiture of instrumentalities and proceeds is possible in addition to a criminal sanction but also instead of a criminal sanction ( $\S 73-75$ StGB). $§ 375$ (2) AO allows the confiscation of the products, goods and other items used for or obtained by tax evasion and amends the general rules in $\S \S$ 73-75 StGB. E.g. according to $\S 73$ (1) StGB, objects, which the perpetrator "obtained through" the unlawful act, are to be confiscated. In the case of tax evasion, this is the monetary advantage in the form of the tax owed. Since the collection of this "something" is not possible due to its nature, the court orders the collection of an amount of money corresponding to the tax reduction (value replacement) according to $\S 73 \mathrm{c}$ sentence $1 \mathrm{StGB}$. Pursuant to $\S 459 \mathrm{~h}$ (2) StPO, the proceeds from the realization of the proceeds are paid "to the injured party who has a claim to compensation for the value of the proceeds from the offence". The injured party may also be the tax authorities. The public prosecutor's office, as the executing authority, decides on the claim to which the injured party is entitled. Only the amount corresponding to the tax claim may be paid out. ${ }^{101}$

In more detail: The goods "to which the evasion of excise duties relates" are not obtained through tax evasion as such. They are therefore not directly subject to forfeiture pursuant to $\S 73$ StGB. However, they can still be confiscated because of the specific regulation under $\S 375$ (2) Sentence 1 No. 1 AO. If the perpetrator has sold the goods before the decision, it lies within the discretionary power of the court to order that some compensation (Wertersatz) be paid up to the amount which corresponds to the value of the object pursuant to $\S 74 \mathrm{c} \mathrm{StGB} .{ }^{102}$

The confiscation of the means of transport used for the offence is permitted according to $\S 375$ (2) Sentence 1 No. 2 AO. This includes preceding or following escort vehicles. ${ }^{103}$ The reference in $\S 375$ (2) Sentence 2 AO to $\S 74 \mathrm{a}$ StGB enables the confiscation of objects if the person who owns or is entitled to them has at least recklessly ("leichtfertig") contributed to the fact that the object or the right was the instrument or object of the act or its preparation. ${ }^{104}$ According to $\S 369$ (2) AO, the general provisions on confiscation of crime products, means of crime and objects of crime ( $\$ 74$ ff. StGB) apply additionally, unless $\S 375$ (2) AO provides otherwise. This is the case for those items which fulfil only the general characteristics of $\S$ 74 (1) StGB, i.e. which were the result of an intentional - at least attempted and as such punishable-offence or were used or intended for its commission or preparation.

\footnotetext{
${ }^{101}$ Bauer (2018), pp. 89-90; see also Weidemann (2018), pp. 49-50.

${ }^{102}$ Jäger (2017), pp. 522-523.

${ }^{103}$ Bundesgerichtshof (BGH) Einziehung des Sicherungsfahrzeuges (1952) 2 StR 354/52, BGHSt 3,355 .

${ }^{104}$ Bundesgerichtshof (BGH) Einziehung von Transport- und Begleitfahrzeugen (2016) 1 StR 118/16, NStZ 2016, 731.
} 
Only objects which were created directly through the act (producta sceleris) are produced by the act ( $\$ 74$ (1) Alt. 1 StGB). Proceeds from the sale of goods do not fall under this category, so that this alternative has no practical significance in criminal tax law apart from $\S 150$ StGB and $\S 375$ (2) AO. ${ }^{105}$ Objects which were used or intended to be used as a means or tools for the commission of an offence or its preparation and which have promoted or should have promoted the offence (instrumenta sceleris), e.g. a mobile telephone, are used (§ 74 (1) Alt. 2 StGB) or intended to be used ( $\$ 74$ (1) Alt. 3 StGB) for the commission of an offence are also covered. However, even if it is proven that a telephone was used during the crime, the confiscation order is not possible if the content of the call cannot be clarified in detail. ${ }^{106}$ Objects which were used after the crime had been committed but before it ended, e.g. suitcases for transporting the smuggled goods after crossing the border, can also be confiscated under certain conditions. ${ }^{107}$ According to $\S 150$ StGB it is compulsive to confiscate false or devalued tax stamps and the respective counterfeit means in case of tax stamp offences $(\S \S 148,149 \mathrm{StGB}) .{ }^{108}$

\subsubsection{Sanctions for Administrative Offences}

For administrative offenses the only sanction is a fine ( $\$ 1 \mathrm{OWiG})$. If the specific offense does not provide otherwise, intentional conduct is fined by a maximum of 1000 EUR and negligent conduct by a maximum of 500 EUR ( $\$ 17$ OWiG). Tax offences in most cases provide for a higher sentence as an exception to this general rule: $\S 378$ AO (up to 50,000 EUR), § 379 AO (up to 25,000 EUR), § 381 AO in connection with $\S 60 \mathrm{TabStV}$ or $\S 36 \mathrm{TabStG}$ (up to 5,000 EUR). Confiscation in cases of administrative offenses is only possible if there is a referral to the general rules in the OWiG ( $\S 22-29 \mathrm{a} O \mathrm{OWiG})$, which is not the case for $\S \S 378-383 \mathrm{AO}$ as well as for $\S 60$ TabStV and $\S 36$ TabStG. But it applies to $\S 37$ (3) TabStG in the case of confiscation of no more than 1000 cigarettes per act traded on the black market. ${ }^{109} \S 375 \mathrm{AO}$ is not applicable to administrative offences.

\subsubsection{Other Sanctions}

In addition to these consequences further administrative measures with a sanctioning effect can apply. Among these are the withdrawal of licenses for exercising a trade $(\S$

\footnotetext{
${ }^{105}$ Wegner (2015b), § 375 AO para. 31 .

${ }^{106}$ Wegner (2015b), § 375 AO para. 32.

${ }^{107}$ Bundesgerichtshof (BGH) Einziehung von Tatwerkzeugen (2004) 2 StR 362/04, StV 2005, 2103.

${ }^{108}$ Hilgers-Klautzsch (2017), § 375 AO para. 40.

${ }^{109}$ Hilgers-Klautzsch (2017), § 375 AO para. 39-40.
} 
35 (1) GewO), the withdrawal of firearms licenses or the refusal to issue a hunting license ( $\$ 17 \mathrm{BJagdG}){ }^{110}$

\subsection{Liability and Sanctions for Illicit Trade of Tobacco Products (Legal Persons)}

German criminal law does not provide for corporate criminal liability in the criminal code. Yet, legal entities can be subject to criminal confiscation orders under $\S 73 \mathrm{~b}$ StGB (e.g., if a company obtained some gain from smuggling committed by its staff). Also, the OWiG provides for a corporate fine in case of violations of criminal and administrative offences by senior staff of the legal entity ( $\$ 30 \mathrm{OWiG})$. The company is responsible if a senior staff member commits either a criminal or an administrative offense in his capacity as a corporate member. In these cases fines up to $€ 10$ million for intentional crimes or up to $€ 5$ million in negligence cases are possible. As the illegal gain can be added to this, confiscation can be part of an overall fine. In the Volkswagen (VW) emission case, VW was fined $€ 1$ billion, consisting of $€ 5$ million for the punitive part and €995 million for the confiscation part. Although Germany in this regard has a corporate liability system, there is a vigorous debate to modernize the system and increase the pressure on companies. The state of Northrhine-Westfalia ${ }^{11}$ has proposed a respective bill in 2013, the federal government is currently working on a proposal that includes increased sanctions and new rules for internal investigations, cooperation with authorities, and compliance.

\subsection{Disposal or Destruction of Confiscated Tobacco Products}

Illegal tobacco products can often be secured and transferred to the ownership of the federal government (see e.g. $\S 23$ (1) Sentence 5 TabStG in conjunction with $\S \S$ 215, 216 AO, see also $\S 111 \mathrm{~b}$ StPO). In cases of a criminal offense the StGB allows for the confiscation of the goods (that normally have been secured before brought into public custody). According to $\S 75$ StGB the state becomes owner of the confiscated goods when the confiscation order is final. Illegal goods are then regularly destroyed.

\footnotetext{
${ }^{110}$ Jäger (2018), § 370 AO para. 348-349.

${ }^{111}$ Land Nordrhein-Westfalen (2013). See Zieschang (2014), p. 91; Schlagowski (2018).
} 


\subsection{WTO FCTC and the 2012 Protocol}

Germany has signed and ratified the FCTC ${ }^{112}$ and the 2012 Protocol. ${ }^{113}$ The FCTC was mainly implemented by implementing Directive 2014/40/EU and its following European legislation. ${ }^{114}$ It has been disputed if Art. 13 FCTC has been sufficiently implemented as Germany does not completely ban tobacco advertising, promotion and sponsorship. ${ }^{115}$ Yet, as the obligation leaves some discretion in regard to the implementation strategy the German approach is to be seen still in line of the minimum requirements. ${ }^{116}$ In regard to Art. 14 of the 2012 Protocol German law basically covers the mentioned acts especially under its main criminal and administrative tax offenses, $\S \S 370-374 \mathrm{AO}$ and $\S \S 378,381$ (in conjunction with $\S$ $60 \mathrm{TabStV}$ and $\S 36 \mathrm{TabStG}) \mathrm{AO} .{ }^{117}$ The requirement of corporate criminal liability (Art. 15 of the 2012 Protocol) is fulfilled by the regulation in $\S 30 \mathrm{OWiG}^{118}$

\section{Procedural Law Issues}

As tax criminal law is criminal law the normal criminal procedure rules apply, apart from some specialties mainly in regard to custom duties. ${ }^{119}$ As custom duties are an exclusive legislative competence of the federal government (Art. 105 (1) GG) all fiscal authorities in the customs area (so-called customs administration) are federal

\footnotetext{
112“"Gesetz zu dem Rahmenübereinkommen der Weltgesundheitsorganisation vom 21. Mai 2003 zur Eindämmung des Tabakgebrauchs (Gesetz zu dem Tabakrahmenübereinkommen)" of 19 November 2004, BGB1. II p. 1538.

113“"Gesetz zu dem Protokoll vom 12. November 2012 zur Unterbindung des unerlaubten Handels mit Tabakerzeugnissen" of 17 July 2017, BGB1. II p. 1538.

${ }^{114}$ See the relevant legislation: Gesetz zur Umsetzung der Richtlinie über Tabakerzeugnisse und verwandte Erzeugnisse of 4 April 2016, BGBl. I p. 569; Verordnung zur Umsetzung der Richtlinie über Tabakerzeugnisse und verwandte Erzeugnisse of 27 April 2016, BGB1. I p. 980; Erste Verordnung zur Änderung der Tabakerzeugnisverordnung of 21 June 2016, BGB1. I p. 1468; Zweite Verordnung zur Änderung der Tabakerzeugnisverordnung of 17 May 2017, BGBl. I p. 1201; Dritte Verordnung zur Änderung der Tabakerzeugnisverordnung of 2 May 2019, BGB1. I p. 547.

${ }^{115}$ Critical on the issue, e.g. several parliamentary members of the Green Party, see the parliamentary document BT-Drs. 17/2036 (of 10 June 2010). For a general ban see the parliamentary motion in BT-Drs. 19/2539 (of 6 June 2018).

${ }^{116}$ See Streinz (2017).

${ }^{117}$ See also the evaluation of the Government on the implementation status of the protocol under German law in BT-Drs. 18/11868, pp. $40 \mathrm{ff}$. Within the scope of this report it is not possible to evaluate Art. 14 of the 2012 protocol and its implementation status in detail.

${ }^{118}$ See BT-Drs. 18/11868, p. 41.

${ }^{119}$ See Harder (2014), Chapter 22 para. 1 ff.; Krause and Prieß (2014), § 34 para. 1 ff.; Retemeyer and Möller (2015), Chapter 20 para. 1 ff.
} 
authorities that are assigned to the Federal Ministry of Finance. ${ }^{120}$ The customs administration, the main customs offices (Hauptzollamt) and the customs investigation service (Zollfahndungsdienst), have been separate branches until 2015, but since then and the reorganization of the customs administration are combined under the single umbrella of the General Customs Directorate (Generalzolldirektion) as the supreme authority. However, the 43 main customs offices and the eight customs investigation offices remained unchanged as local authorities. ${ }^{121}$ The Customs Criminal Investigation Office (Zollkriminalamt-ZKA), as the central office of the Customs Investigation Offices, was integrated as Directorate in the General Customs Directorate. The directorate of the ZKA and the customs investigation offices have a considerable number of staff. ${ }^{122}$

The main customs offices are tasked besides the prosecution services with the investigation of and partly the prosecution of criminal and administrative customs offenses. ${ }^{123}$ The customs offices are responsible if the case only involves customs offenses. If not, the prosecution is responsible (but can ask the custom offices for assistance). The custom authorities have a similar power as the tax authorities in regard to taxes. Insofar as these independently conduct a customs criminal procedure, they, like the tax authorities, have individual public prosecutorial powers. ${ }^{124}$ Particularities arise from the extensive competences in preliminary investigations at the borders, where, in principle, the investigations are carried out by border customs officers assigned to the main customs offices. ${ }^{125} \mathrm{Here}$, controls without suspicion are possible as part of the regular customs supervision, but which can as well lead to criminal proceedings (for example due to customs offenses or money laundering).

An example of the powers at the borders is the 2017 introduced § 12e (1) ZollVG, which allows the seizure (Sicherstellung) of excise goods, in particular cigarettes, and raw materials (e.g. tobacco) and machinery suitable for their manufacture, as well as the associated containers and enclosures until the end of the fifth working day after their discovery. ${ }^{126}$ These measures are intended to verify the lawfulness of the use of the goods. The only requirement is that an assumption has to be established that these goods are transferred with the intention of committing a tax offence under $\S 369$ AO. This makes it possible to temporarily stop such goods at the border, without regard to the threshold of an initial suspicion in a normal criminal proceedings. ${ }^{127}$

\footnotetext{
${ }^{120}$ See $\S 1$ Gesetz über die Finanzverwaltung (FVG).

${ }^{121}$ See Gesetz zur Neuorganisation der Zollverwaltung v. 3.12.2015, BGB1. I S. 2178.

${ }^{122}$ In 2017 the ZKA employed 944 persons and the eight customs investigation offices 2435 persons, see Generalzolldirektion, Der Zoll. Jahrestatistik 2017, p. 19.

${ }^{123} \S 386$ Abs. 1 AO. For an overview of the agencies involved see Calderoni et al. (2013), pp. $48 \mathrm{ff}$.

${ }^{124}$ Vgl. Krause and Prieß (2014), § 34 para. 153.

${ }^{125}$ Wirth (2005), pp. $31 \mathrm{ff}$.

${ }^{126}$ Weerth (2018), pp. F19-F20.

${ }^{127}$ Häberle (2018), § 12e ZollVG para. 1.
} 
The customs investigation service, which includes the ZKA and the customs investigation offices ( $(1 \mathrm{ZFdG})$, also has its own special investigative powers. Even though the latter is not himself a law enforcement agency, in practice the facts (as in the case of the tax investigation department, the Steuerfahndung) are regularly completely determined by the agency and then sent to the main customs office for a decision. ${ }^{128}$ The Customs Criminal Office takes over the investigation only in exceptional cases and mainly supports the work of the customs investigation offices by providing information and coordinating the case. ${ }^{129}$ The customs investigation has police powers (such as the Steuerfahndung) in the customs area under the AO and StPO. ${ }^{130}$

Like the Steuerfahndung, the customs investigation department has the competence to conduct preliminary investigations in the customs procedure which it also has to carry out. ${ }^{131}$ Insofar, in addition to prosecution tasks, it is assigned extensive preventive tasks, too, and has in this regard, numerous powers, in particular for information acquisition and processing. ${ }^{132}$ Prevention and repression go hand in hand as "preventing and prosecuting crimes and offenses" as well as "uncovering unknown crimes" and "preparing for future criminal cases". 133

The ZKA manages and manages an extensive collection of data. ${ }^{134}$ In that regard, the ZKA is similar to the Federal Police Office (Bundeskriminalamt-BKA) in terms of the breadth of tasks and the nature of an information administration office. The collection includes both preventive and repressive data. ${ }^{135}$ The ZKA has special powers, e.g., it may preventively monitor telecommunication in the event of suspicion of the preparation of certain crimes. ${ }^{136}$ This data may in principle be used for both preventive and repressive purposes. ${ }^{137}$ In general, § 393 (3) Sentence 1 AO allows that lawfully obtained findings of tax authorities or the public prosecutor's office in the course of criminal investigations may also be used in taxation proceedings.

Besides the aforementioned examples "normal" investigation measures can also be referred to. Pursuant to $\S 100 \mathrm{a}$ (2) No. 2 a, b StPO it is possible to monitor electronic communications of suspects in the case of serious tax crimes (especially in gang cases or where a commercial conduct is given). ${ }^{138}$ Furthermore, investigative

\footnotetext{
${ }^{128}$ Krause and Prieß (2014), § 34 para. 152.

${ }^{129}$ See on the tasks $\S \S 3 \mathrm{ff} ., 24 \mathrm{f}$. ZFdG and Linke (2004), pp. $143 \mathrm{ff}$.

${ }^{130}$ See for details Harder (2014), Chapter 22 para. $30 \mathrm{ff}$.

${ }^{131}$ Krause and Prieß (2014), $\S 34$ para. 155 ff.; Fehn (2006), Chapter B para. 8 ff.

${ }^{132}$ See $\S \S 7-23 \mathrm{~g}, 26-38 \mathrm{ZFdG}$.

${ }^{133}$ See $\S 24$ Abs. 2 ZFdG.

${ }^{134} \S \S 7-13 \mathrm{ZFdG}$.

${ }^{135}$ For detail see Lenz (2006), Chapter C para. $173 \mathrm{ff}$.

${ }^{136}$ See $\S \S 23 \mathrm{a}$ ff. ZFdG (covering offenses against the German Weapons Control Act); critical Wachner (2006), Chapter H para. 194 ff.

${ }^{137} \S 23 \mathrm{~d} \mathrm{ZFdG}$.

${ }^{138}$ Bauer (2018), p. 87; Bittmann (2010), p. 125.
} 
measures may include long-term observation ("controlled transport") according to $\S$ $163 \mathrm{f} \mathrm{StPO}$ or the use of undercover investigators under $\S 110 \mathrm{a}$ (1) No. 3, 4 StPO. $\S \S$ 110 a et seq. StPO allows covert investigations. Of particular importance is the provision of $\S 100 \mathrm{~g}$ StPO for obtaining information on telecommunications connections. ${ }^{139}$

In order to safeguard the enforcement of monetary claims German law provides for several measures. Among these are $\S 111 \mathrm{~b}$ StPO that allows objects to be secured by seizure until a final decision on forfeiture. $\$ 324$ AO allows a freezing injunction for movable or immovable assets where there are reasons to fear that recovery for tax monetary claims will otherwise be thwarted or seriously hindered.

From a legal perspective in the custom offense cases the determination of the course of the transport process is particularly important for the distinction between $\S \S 370,373 \mathrm{AO}$ on the one hand and $\S 374 \mathrm{AO}$ (Steuerhehlerei) on the other during the investigation procedure. Especially the question of whether the import operation (from a non-EU-country) has already been completed at the time of participation is decisive for the question of criminal liability. This is important for perpetrators, who obtain tobacco products which have previously been imported into the EU by third parties in another EU Member State for the purpose of further transfer to the Federal Republic of Germany. Then, the offences of evasion of import duties or the evasion of tobacco tax is only completed when the tobacco goods have been brought to safety and "come to rest". ${ }^{140}$ Yet, in practice in many cases, the smuggled goods are only seized and secured by customs authorities in Germany without investigating the question of how long the imported goods had already been (temporarily) stored in the other EU member state. This is unfortunate if it is ascertainable that the import procedure was already completed in the other EU member state because the persons involved in the onward transport to Germany also carry out tax fraud with regard to import duties (in accordance with $\S 374 \mathrm{AO}$ ) in addition to the evasion of the German tobacco tax ( $\$ 370,373 \mathrm{AO}) .^{141}$

The jurisprudence also tries to facilitate speedy proceedings. E.g., in order to save the courts from having to make difficult findings about foreign tobacco tax law, the Federal Court, the $\mathrm{BGH}$, permits the courts to restrict prosecution under $\S \S 154$; 154a StPO to the German transfer tobacco tax (in addition to the import turnover tax and customs duty) and not to extend it to the transfer tax incurred in other Member States. ${ }^{142}$

Altogether, dealing with custom offenses requires formidable resources since the costs for personnel deployment and especially technical investigation measures such as telephone surveillance are enormous. This is especially true in cross-border investigations. Especially in such investigations resource inadequacies are taken advantage of by perpetrators in a targeted manner. Enhanced cooperation and

\footnotetext{
${ }^{139}$ Koziolek (2015a), p. 211.

${ }^{140} \mathrm{BGH}$, wistra 2016, 74 (n 20).

${ }^{141}$ Bauer (2018), p. 85.

${ }^{142}$ BGH, NStZ 2010, 644 (n 21).
} 
Table 1 Number of economic and tax crime cases in $2017^{\mathrm{a}}$

\begin{tabular}{l|r}
\hline Economic- and tax crime cases, money-laundering cases & 135,836 \\
\hline Economic crime cases (according to § 74c GVG) & 5007 \\
\hline Other economic crime cases & 65,792 \\
\hline Tax crime cases & 21,012 \\
\hline Money laundering cases (§ 261 StGB) & 41,049 \\
\hline Other cases within $§ 74 \mathrm{c}$ Abs. 1 GVG & 2976 \\
\hline
\end{tabular}

${ }^{a}$ Statistisches Bundesamt (Destatis), Rechtspflege: Staatsanwaltschaften 2017: Fachserie 10 Reihe 2.6 Statistisches Bundesamt (Destatis) (2018a), p. 22

networking of police, customs and prosecution services involved in the fight against illicit trade is therefore to be aimed at, also it might be effective to establish central offices or include these offenses in the mandate of the European Public Prosecutor's Office. $^{143}$

\section{Criminological Data}

Sound information on the scope, the investigation and the adjudication of the illicit trade of tobacco products in Germany is scarce as there is often only information available on criminal offenses (and not on administrative offenses) and on tax offenses in general (but not on the percentage of custom offences etc.). The main resources for statistical data are the police statistics (Polizeiliche Kriminalstatistik) and the tables for the judiciary (Rechtspflegestatistik). In addition, some authorities such as the customs offices provide further information. In the following, only the available data is presented. The tables referred to in the text are part of the annex.

\subsection{Investigation of Illicit Trade of Tobacco Products}

The general statistics of the judiciary give a general overview on the number of economic and tax crime cases investigated (see Table 1).

115.857 cases were initiated in 2017 by the tax investigation department (Steuerfahndung) and the customs investigation service (Zollfahndungsdienst) in regard to all subject matters these authorities are responsible for. ${ }^{144}$

The number of cases investigated by the tax investigation department (Steuerfahndung) in the field of tax and custom offences is quite considerable with

\footnotetext{
${ }^{143}$ See Koziolek (2015a), p. 211.

${ }^{144}$ Statistisches Bundesamt (Destatis), Rechtspflege: Staatsanwaltschaften 2017: Fachserie 10 Reihe 2.6 (Statistisches Bundesamt (Destatis) 2018a, p. 20).
} 
Table 2 Completed investigations of the tax investigation department (Steuerfahndung) from 2000 to $2016^{\mathrm{a}}$

\begin{tabular}{l|c}
\hline Year & No. of completed investigations \\
\hline 2000 & 48,638 \\
\hline 2001 & 45,792 \\
\hline 2002 & 46,729 \\
\hline 2003 & 42,393 \\
\hline 2004 & 37,370 \\
\hline 2005 & 36,195 \\
\hline 2007 & 35,666 \\
\hline 2008 & 36,309 \\
\hline 2009 & 31,537 \\
\hline 2010 & 31,878 \\
\hline 2011 & 34,186 \\
\hline 2013 & 35,592 \\
\hline 2014 & 31,655 \\
\hline 2015 & 34,183 \\
\hline 2016 & 40,241 \\
\hline
\end{tabular}

${ }^{\mathrm{a}}$ Figures by the Federal Ministry of Finance, Verfolgung von Steuerstraftaten und Steuerordnungswidrigkeiten (various monthly reports), www.bundesfinanzministerium.de

Table 3 Completed investigations of custom investigation service (Zollfahndungsdienst) from 2011 to $2018^{\mathrm{a}}$

\begin{tabular}{l|l}
\hline Year & No. of completed investigations \\
\hline 2011 & 2057 \\
\hline 2012 & 1935 \\
\hline 2013 & 1342 \\
\hline 2014 & 1306 \\
\hline 2015 & 1217 \\
\hline 2016 & 1149 \\
\hline 2017 & 995 \\
\hline
\end{tabular}

${ }^{a}$ Figures provided by Generalzolldirektion-Zollkriminalamt, Fachgebiet B.322 (Bekämpfung der Tabakwarenkriminalität)

36,667 cases in 2016 (see Table 1). Yet, it has generally decreased since 2000, when there were 48,638 cases (see Table 2).

The figures of the customs investigation service (Zollfahndungsdienst) on customs offenses investigations also shows a decrease in numbers in recent years (see Table 3).

This means that the overall number of cases (1.261 cases in 2018, see Table 2 ) is much lower than the ones of the Steuerfahndung, although this data does not include the investigations by the 43 principal customs offices (Hauptzollämter). The German government stated in 2018 (based on information by the custom offices) that within the last 12 months 3826 investigations took place in regard to tax crimes in 
connection cigarettes and another 1108 investigations in regard to illegal tobacco products (including cigarettes) were initiated. ${ }^{145}$

Additional information stems, e.g., from the Federal Criminal Police Office (Bundeskriminalamt-BKA) that listed 48 investigations of tax and custom offences in regard to organized crime in 2017 (decrease of $15.8 \%$ compared to 2016 ). ${ }^{146} 8.4 \%$ of these organized crime offences concerned taxes and customs. ${ }^{147}$ An illustrative example is provided by the city of Berlin that lists 741 cases of suspected violations of the AO in the context of illicit trade of cigarettes in $2016 .{ }^{148}$ The police imposed 570 measures implying restrictions of freedoms. Among them were 19 arrest warrants.

\subsection{Prosecution/Convictions in Cases of Illicit Trade of Tobacco Products}

There is hardly any information on the number of prosecutions in cases of illicit trade of tobacco products. Information available is, e.g., on preliminary proceedings in the area of organized crimes, that includes organized crime in regard to tax and custom offences. The numbers have steadily declined between 2000 (854) and 2017 (572) (see Table 4).

In regard to adjudicated cases information is available in regard to the specific offenses in the AO (see Table 5). In 2002 there were altogether 11,288 judgements and 10,161 convictions for offenses in the AO. ${ }^{149}$ In 2017 the number has increased to 12,551 judgements and 11,051 convictions with the large majority of cases being tax evasion according to $\S 370 \mathrm{AO}$.

There is no specific data on penalties in regard to customs offenses or the illicit traffic of tobacco goods. The information on sanctions for all offenses in the AO

\footnotetext{
${ }^{145}$ Deutscher Bundestag (BT), 'Steuerschäden durch Tabak- und Zigarettenschmuggel: Antwort der Bundesregierung auf die Kleine Anfrage der Abgeordneten Markus Herbrand, Christian Dürr, Dr. Florian Toncar, weiterer Abgeordneter und der Fraktion der FDP - Drucksache 19/6263 -', 19 December 2018, BT-Drucksache 19/6644.

${ }^{146}$ Bundeskriminalamt, Organisierte Kriminalität, Bundeslagebild 2017, Wiesbaden April (2018), pp. 5, 33-34.

${ }^{147}$ Bundeskriminalamt, Organisierte Kriminalität, Bundeslagebild 2017, Wiesbaden April (2018), p. 5.

${ }^{148}$ See the answer to a parliamentary request in 2017: Abgeordnetenhaus Berlin, 'Schriftliche Anfrage des Abgeordneten Peter Trapp (CDU) vom 29. Mai 2017 (Eingang beim Abgeordnetenhaus am 30. Mai 2017) zum Thema Illegaler Zigarettenhandel in Berlin im Jahr 2016 und Antwort vom 12. Juni 2017 (Eingang beim Abgeordnetenhaus am 14. Juni 2017)' Drucksache 18/11328, p. 2.

${ }^{149}$ Statistisches Bundesamt (Destatis), 'Rechtspflege: Strafverfolgung: Fachserie 10 Reihe 3' (2002), table 2.1. The table does not yet go into more details.
} 
Table 4 Preliminary proceedings in the area of organized crime from 2000 to 2017

\begin{tabular}{l|l|l|l}
\hline Year & Total & Initial reports & Pending cases \\
\hline 2000 & 854 & 473 & 381 \\
\hline 2001 & 787 & 389 & 398 \\
\hline 2002 & 690 & 338 & 352 \\
\hline 2003 & 637 & 327 & 310 \\
\hline 2004 & 620 & 307 & 313 \\
\hline 2005 & 650 & 345 & 305 \\
\hline 2006 & 622 & 308 & 314 \\
\hline 2007 & 602 & 295 & 307 \\
\hline 2008 & 575 & 271 & 304 \\
\hline 2009 & 579 & 305 & 274 \\
\hline 2010 & 606 & 318 & 288 \\
\hline 2011 & 589 & 318 & 271 \\
\hline 2013 & 568 & 278 & 290 \\
\hline 2014 & 580 & 298 & 282 \\
\hline 2015 & 571 & 299 & 272 \\
\hline 2016 & 563 & 271 & 285 \\
\hline 2017 & 572 & 274 & 288 \\
\hline & & & 298 \\
\hline
\end{tabular}

Table 5 Adjudicated offenses of the $\mathrm{AO}^{\mathrm{a}}$

\begin{tabular}{|c|c|c|}
\hline Type of offense & No. of judgements & No. of convictions \\
\hline All tax- and custom offenses in the $\mathrm{AO}$ & 12,551 & 11,051 \\
\hline$\S 370(1) \mathrm{AO}$ & 11,808 & 10,443 \\
\hline$\S 370(3) \mathrm{AO}$ & 243 & 225 \\
\hline$\S 372(2) \mathrm{AO}$ & 23 & 21 \\
\hline$\S 373(1) \mathrm{AO}$ & 20 & 17 \\
\hline$\S 374(1) \mathrm{AO}$ & 240 & 209 \\
\hline$\S 374(2) \mathrm{AO}$ & 68 & 62 \\
\hline Other offenses in the AO & 149 & 74 \\
\hline
\end{tabular}

${ }^{a}$ Statistisches Bundesamt (Destatis), 'Rechtspflege: Strafverfolgung: Fachserie 10 Reihe 3' Statistisches Bundesamt (Destatis) (2018b), p. 86

shows that in the majority of cases a fine is the only sanction. Forfeiture orders did apply in $6.8 \%$ of the cases (see Table 6).

In about $11 \%$ of the cases an imprisonment sanction has been referred to, in most cases for a period between 9 months and 2 years (see Table 7).

No detailed information on the number of legal persons convicted in regard to illicit trade of tobacco products exists. The overall number of convicted legal persons according to $\S 30 \mathrm{OWiG}$ (and insofar in conjunction with all criminal and administrative offenses) ranges between about 2000 and 4000 per year (see Table 8). 
Table 6 Sanctions for offenses in the $\mathrm{AO}^{\mathrm{a}}$

\begin{tabular}{l|l|r|l|l}
\hline Offenses & $\begin{array}{l}\text { Total no. of } \\
\text { convictions }\end{array}$ & Fines & $\begin{array}{l}\text { Convictions with } \\
\text { imprisonment }\end{array}$ & Forfeiture \\
\hline $\begin{array}{l}\text { All Tax- and custom offenses } \\
\text { in the AO }\end{array}$ & 11,051 & 9812 & 1239 & 749 \\
\hline$\S 370(1)$ AO & 10,443 & 9514 & 929 & 638 \\
\hline$\S 370(3)$ AO & 225 & 45 & 18 & 17 \\
\hline$\S 372(2)$ AO & 21 & 17 & 4 & 3 \\
\hline$\S 373(1)$ AO & 17 & 4 & 13 & 3 \\
\hline$\S 374(1)$ AO & 209 & 138 & 71 & 65 \\
\hline$\S 374(2)$ AO & 62 & 27 & 35 & 9 \\
\hline Other offenses in the AO & 74 & 67 & 7 & 14 \\
\hline
\end{tabular}

${ }^{a}$ Statistisches Bundesamt (Destatis), 'Rechtspflege: Strafverfolgung: Fachserie 10 Reihe 3' (Statistisches Bundesamt (Destatis) 2018b)

\subsection{Financial Impact of Illicit Trade of Tobacco Products}

There are no exact figures on the financial impact of illicit trade of tobacco products. An assessment by Bräuninger/Stiller of the Hamburg Institute of International Economics (HWWI) estimates that in recent years, about $20 \%$ of cigarettes consumed in Germany have not been taxed in Germany. ${ }^{150}$ This corresponds to a volume of approx. 23 billion units, whereof at least seven billion are estimated to have been brought illegally to Germany. The resulting tax loss amounts to at least 4.0 billion EUR, and the additional damage to industry and trade amounts to at least 1.2 billion EUR.

According to the Project SUN by the professional service company KPMG, 4.2 billion of smuggled or counterfeited tobacco products constitute an estimated tax loss (VAT and tobacco tax) of 845 million EUR in 2017, provided that all those tobacco products would have been purchased legally otherwise. ${ }^{151}$

The German Cigarette Association ("Zigarettenverband") assumes that in 2011, 23.5 billion untaxed cigarettes were smoked. 19.9 billion out of 23.5 billion cigarettes $(85 \%)$ were bought in another member state of the European Union or as dutyfree goods. The association estimates tax losses of 5.5 billion $€$ (for 23.5 billion cigarettes). ${ }^{152}$ According to the association the estimated market share of untaxed cigarettes fluctuates between $16.1 \%$ (2005) and $22.1 \%$ in 2011 , and in recent years very stable at about $18 \%$ (see Table 9), while the value of cigarettes sold in Germany

\footnotetext{
${ }^{150}$ Bräuninger and Stiller (2010), p. 21.

${ }^{151}$ KPMG (2017).

${ }^{152}$ See the press release Deutscher Zigarettenverband (15 Feb. 2012) Neuer Rekord beim Zigarettenschmuggel: Deutsche rauchen über 23 Milliarden Zigaretten am Fiskus vorbei! https:// www.zigarettenverband.de/pos-data/page_img/Publikationen/Pressemitteilungen/2012-15-02-PMSchmuggelzahlen.pdf. Accessed 15 May 2019.
} 


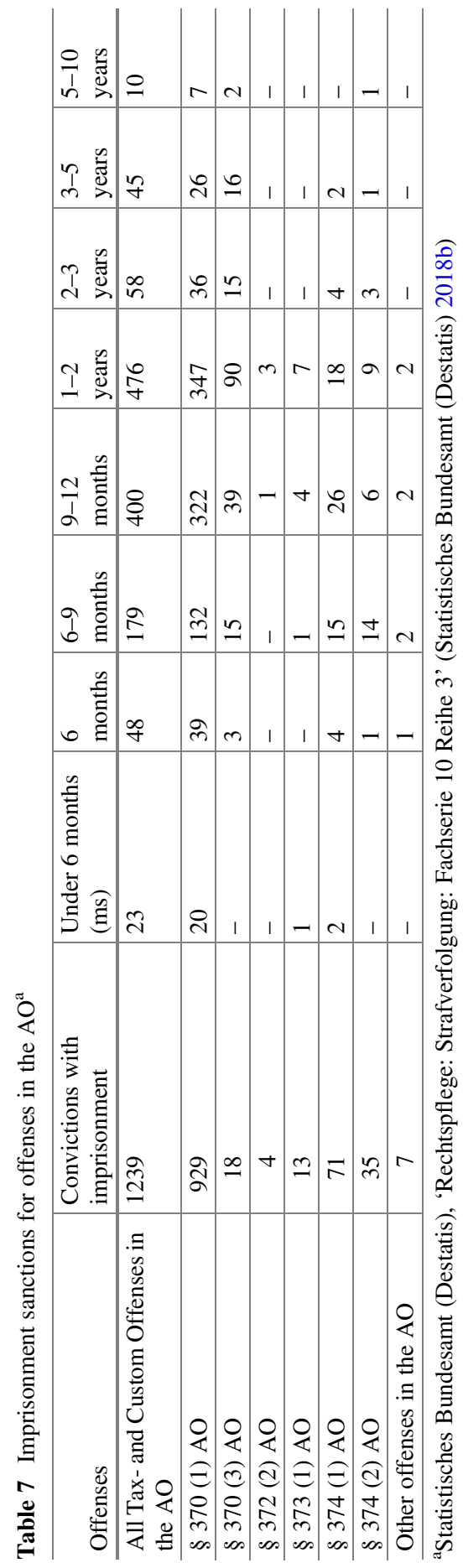


Table 8 Corporate fines according to $\S 30 \mathrm{OWiG}^{\mathrm{a}}$

\begin{tabular}{l|l}
\hline Year & Total no. of fines per years \\
\hline 2000 & 3295 \\
\hline 2001 & 4067 \\
\hline 2002 & 2286 \\
\hline 2003 & 4745 \\
\hline 2004 & 2804 \\
\hline 2006 & 1911 \\
\hline 2007 & 2222 \\
\hline 2008 & 2487 \\
\hline 2009 & 2483 \\
\hline 2011 & 2617 \\
\hline 2012 & 2871 \\
\hline 2013 & 2273 \\
\hline 2014 & 3035 \\
\hline 2015 & 2871 \\
\hline 2016 & 3243 \\
\hline
\end{tabular}

${ }^{\text {a }}$ Figures by the Federal Office of Justice (Bundesjustizamt): Übersicht über die Eintragungen im Gewerbezentralregister (Teilregister juristische Personen und Personenvereinigungen), 2000-2017, Table 1

Table 9 Estimated market share of untaxed cigarettes ${ }^{\mathrm{a}}$

\begin{tabular}{l|l|l|l|l}
\hline Year & Germany & West & East & \\
\hline 2005 & 16.1 & 11.6 & 30.6 & in \% \\
\hline 2006 & 19.9 & 15.7 & 33.6 & in \% \\
\hline 2007 & 20.3 & 15.5 & 36.1 & in \% \\
\hline 2008 & 19.9 & 13.8 & 39.7 & in \% \\
\hline 2009 & 20.1 & 13.5 & 41.6 & in \% \\
\hline 2010 & 21.2 & 14.0 & 45.2 & in \% \\
\hline 2011 & 22.1 & 14.5 & 47.6 & in \% \\
\hline 2012 & 20.6 & 14.3 & 44.5 & in \% \\
\hline 2013 & 21.7 & 15.4 & 45.2 & in \% \\
\hline 2014 & 18.9 & 13.2 & 41.6 & in \% \\
\hline 2015 & 17.6 & 12.3 & 37.1 & in \% \\
\hline 2016 & 18.0 & 12.2 & 39.5 & in \% \\
\hline
\end{tabular}

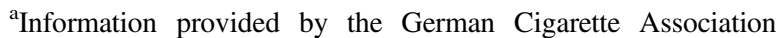
(Deutscher Zigarettenverband) on the basis of studies by the market research institute Ipsos GmbH (Hamburg), see https:// www.zigarettenverband.de/de/18/Themen/Zahlen_\&_Fakten/ Nicht_Versteuerter_Zigarettenabsatz (as of 15 May 2019) 
Table 10 Value of cigarettes sold in Germany ${ }^{\mathrm{a}}$

\begin{tabular}{|c|c|}
\hline Year & Revenue ("Kleinverkaufswert") in Million EUR \\
\hline 1979 & $9,181.60$ \\
\hline 1985 & $11,397.40$ \\
\hline 1991 & $15,888.80$ \\
\hline 2000 & $19,175.90$ \\
\hline 2005 & $19,532.50$ \\
\hline 2006 & $19,913.35$ \\
\hline 2007 & $19,992.47$ \\
\hline 2008 & $19,424.98$ \\
\hline 2009 & $19,624.97$ \\
\hline 2010 & $19,199.77$ \\
\hline 2011 & $20,643.15$ \\
\hline 2012 & $20,106.01$ \\
\hline 2013 & $20,147.18$ \\
\hline 2014 & $20,461.55$ \\
\hline 2015 & $21,696.76$ \\
\hline 2016 & $20,520.88$ \\
\hline 2017 & $21,377.47$ \\
\hline 2018 & $21,659.30$ \\
\hline
\end{tabular}

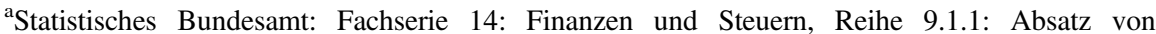
Tabakwaren. A compilation is found on the Website of the German Cigarette Association (Deutscher Zigarettenverband), see https://www.zigarettenverband.de/pos-data/page_img/ Grafiken/Infografik/Tab_Absatz_Umsatz_Steuer_2018.pdf (as of 15 May 2019)

varies between 19,532.5 million (2005) and 21,696.76 million (2015), being 21,377.47 million in 2017 (see Table 10).

Although these figures indicate a very high level of tax losses in Germany, it is not possible to validate their accuracy. Reliable dark field studies are not available, ${ }^{153}$ and bright field data can only stem from known financial effects. Especially there exist no reliable information on how big the market share of untaxed cigarettes (compared to all consumed cigarettes) in Germany is. ${ }^{154}$

A first impression gives the amount of confiscated illegal goods (of all sorts) at the border: In 2018 in 37,698 cases more than five million goods with an estimated value of more than 196 million EUR were confiscated (see Table 11, also for the development since 2011). Custom authorities confiscated 62 million cigarettes in 2018, much less than 10 years ago when they confiscated 291 million (see for the years 2008-2018 Table 12). Also, the numbers of confiscated cigarettes by the custom investigation office have dropped significantly since 2010 (see Table 13).

\footnotetext{
${ }^{153}$ See for a critical assessment of the existing studies Adams and Effertz (2011), p. 705; Gallagher et al. (2018), p. 1; Mersmann (2015), pp. 187-192; Stoklosa (2016), p. 360; Taschowsky (2015), p. 28.

${ }^{154}$ See BT-Drucksache 19/6644 (n 146).
} 
Table 11 Confiscation of illegal goods by customs ${ }^{\mathrm{a}}$

\begin{tabular}{l|l|l|l}
\hline Year & $\begin{array}{l}\text { No. of cases of confiscation of } \\
\text { illegal goods at the borders }\end{array}$ & $\begin{array}{l}\text { No. of illegal goods } \\
\text { confiscated in 1.000 }\end{array}$ & $\begin{array}{l}\text { Value of illegal goods } \\
\text { confiscated in million EUR }\end{array}$ \\
\hline 2011 & 23,635 & $2,534.6$ & 82.60 \\
\hline 2012 & 23,883 & $3,202.8$ & 127.40 \\
\hline 2013 & 26,127 & $3,926.9$ & 134.00 \\
\hline 2014 & 45,738 & $5,926.8$ & 137.70 \\
\hline 2015 & 23,338 & $4,025.9$ & 132.30 \\
\hline 2016 & 21,229 & $3,640.1$ & 180.04 \\
\hline 2017 & 21,506 & $3,295.6$ & 196.16 \\
\hline
\end{tabular}

${ }^{a}$ Statista, Anzahl der vom Zoll in Deutschland durchgeführten Beschlagnahmungen von gefälschten Waren sowie Anzahl und Wert der beschlagnahmten Waren von 2012 bis 2018, https://de.statista. $\mathrm{com} / \mathrm{statistik} / \mathrm{daten} / \mathrm{studie} / 155571 /$ umfrage/wert-durch-den-zoll-beschlagnahmter-waren/ (as of 15 May 2019)

Table 12 Amount of confiscated cigarettes by customs from 2008 to $2018^{\mathrm{a}}$

\begin{tabular}{l|l}
\hline Year & Confiscated cigarettes (in million) \\
\hline 2008 & 291 \\
\hline 2009 & 281 \\
\hline 2010 & 157 \\
\hline 2011 & 160 \\
\hline 2012 & 146 \\
\hline 2013 & 147 \\
\hline 2014 & 140 \\
\hline 2015 & 75 \\
\hline 2016 & 121 \\
\hline 2018 & 77 \\
\hline
\end{tabular}

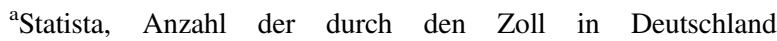
sichergestellten Zigaretten von 2008 bis 2018 (in Millionen Stuick), https://de.statista.com/statistik/daten/studie/29364/ umfrage/sicherstellung-von-zigaretten-in-deutschland/ (as of 15 May 2019)

Concerning the respective tax losses, the investigated tax losses amounted to 153 million EUR in 2010 and dropped to around 38 million EUR in 2018 (see Table 14). The German government received an additional tax revenue of about 3.000 million EUR due to investigations by tax investigation department (Steuerfahndung) from 2002 to 2016 in general including illicit trade of tobacco (see Table 15).

A bright field quantification of tax losses according to the federal ministry of finance on the basis of information from investigation proceedings conducted by the customs offices shows the following development of the tax losses of the past 5 years in regard to tobacco products: 130 million EUR (2014); 120 million EUR (2015); 
Table 13 Amount of confiscated cigarettes by custom investigation service (Zollfahndungsdienst) from 2010 to $2018^{\text {a }}$

\begin{tabular}{l|l|c}
\hline Year & Cigarettes/piece & Tobacco/kg \\
\hline 2010 & $156,958,482$ & 14,536 \\
\hline 2011 & $145,040,585$ & 15,579 \\
\hline 2012 & $132,473,470$ & 1,719 \\
\hline 2013 & $135,623,466$ & 22,760 \\
\hline 2014 & $126,138,076$ & 5,274 \\
\hline 2015 & $68,226,603$ & 1,013 \\
\hline 2016 & $121,357,257$ & 150,604 \\
\hline 2017 & $77,132,481$ & 96,017 \\
\hline
\end{tabular}

${ }^{\mathrm{a}}$ Figures provided by Generalzolldirektion - Zollkriminalamt, Fachgebiet B.322 (Bekämpfung der Tabakwarenkriminalität)

Table 14 Additional tax revenue in million EUR due to investigations by tax investigation department (Steuerfahndung) from 2002 to $2017^{\mathrm{a}}$

\begin{tabular}{l|l}
\hline Year & Additional tax revenue in million EUR \\
\hline 2002 & $1,540.9$ \\
\hline 2003 & $1,628.7$ \\
\hline 2004 & $1,613.4$ \\
\hline 2005 & $1,658.0$ \\
\hline 2006 & $1,433.6$ \\
\hline 2007 & $1,603.8$ \\
\hline 2008 & $1,474.5$ \\
\hline 2009 & $1,565.8$ \\
\hline 2011 & $1,745.7$ \\
\hline 2012 & $2,228.6$ \\
\hline 2013 & $3,079.6$ \\
\hline 2015 & $2,051.2$ \\
\hline 2016 & $2,451.2$ \\
\hline 2017 & $3,025.3$ \\
\hline
\end{tabular}

${ }^{a}$ Statista, Steuermehreinnahmen in Folge von Ermittlungen der Steuerfahndung in Deutschland von 2002 bis 2017 (in Millionen Euro), https://de.statista.com/statistik/daten/studie/257517/ umfrage/anzahl-der-abgeschlossenen-ermittlungen-dersteuerfahndung/ (as of 15 May 2019)

73 million EUR (2016); 89 million EUR (2017); 28 million EUR (first 9 months of 2018)..$^{155}$

${ }^{155}$ See BT-Drucksache 19/6644 (n 146). 
Table 15 Investigated tax loss from 2010 to $2018^{\text {a }}$

\begin{tabular}{l|l}
\hline Year & Investigated tax losses in EUR \\
\hline 2010 & 153.798 .581 \\
\hline 2011 & 102.186 .648 \\
\hline 2012 & 93,4 Mio. \\
\hline 2013 & 174,7 Mio. \\
\hline 2014 & 121.216 .538 \\
\hline 2015 & 114.968 .018 \\
\hline 2016 & 56.994 .476 \\
\hline 2017 & 81.816 .215 \\
\hline
\end{tabular}

${ }^{\mathrm{a}}$ Figures provided by Generalzolldirektion-Zollkriminalamt, Fachgebiet B.322 (Bekämpfung der Tabakwarenkriminalität)

\subsection{Exemplary Cases}

On March 13, 2018, customs discovered 10.4 million cigarettes in a refrigerated truck during a check on the harbor city of Kiel's eastern shore. They were hidden behind cargo (ice). The truck from Estonia should have contained frozen fish. If the cigarettes had been sold in Germany, the treasury would have lost about two million EUR. $^{156}$

Five prosecuted members of gang were convicted for gang and commercial smuggling of cigarettes. ${ }^{157}$ On the basis of the joint plan they carried at least $76,500 \mathrm{~kg}$ of smoking tobacco ("fine cut" of processed tobacco, which can be used without significant intermediate steps for cigarette production), with the incorrect declaration as "tobacco waste" from April to June 2005 via Antwerp into the European Union. It was used for the illegal production of cigarettes in Greece. As a result, import duties of around 424,000 euros were evaded. Also, from July 2005 to February 2011 the gang imported smoking tobacco declared as "tobacco waste" via Klaipeda (Lithuania) to the European Union. As a result, import duties of more than EUR 45 million were withdrawn. The non-duty-paid and untaxed smoking tobacco was used by the group for illegal cigarette production in Poland and Moldova. Their profit from the sale of only the cigarettes produced in Poland between the beginning of 2006 and July 2010 amounted to approximately 54 million euros.

In the so-called "Hydra" case two Joint Investigation Teams (JITs) were set up between the Hanover Customs Office and the customs authorities in Athens and Thessaloniki on the basis of the Naples II Agreement. ${ }^{158}$ These joint investigations required a large number of meetings between the investigators and the implementation of covert action in Greece. In the course of the procedure, OLAF therefore supported this investigation with the financing of flights and provided surveillance

\footnotetext{
${ }^{156}$ Norddeutscher Rundfunk (2018).

${ }^{157}$ Bundesgerichtshof (BGH) Selbstgeldwäsche (2018) 5 StR 234/18, NJW 2019, 533.

${ }^{158}$ Koziolek (2015a), p. 211. See also with more details and on the previous case "Boomerang" Koziolek (2015b), p. 719.
} 
technology to the Greek authorities. As a result of intensive German-Greek investigations, including telephone surveillance measures, it was possible to secure a production facility hidden in a cow barn near Thessaloniki in 2009. A professional assessment of the machine by experts of the Customs and cigarette companies could show a connection between the plant and cigarettes seized in 23 cases throughout Europe. The total volume of cigarette counterfeiting produced on this production line was estimated at more than 300 million cigarettes.

In the so-called "woodworm" (Holzwurm) case, the perpetrators in Russia, the Baltic States, Germany and overseas had founded a large number of companies in tax havens, some of which were also used for legal freight forwarding. ${ }^{159}$ These companies supplied wooden pallets from Russia via Austria and Germany back to the Baltic States and for this purpose issued each other with delivery notes and invoices. In fact, however, only boards prepared with cigarettes were brought to Western Europe. In the case of a single delivery check, this was hardly noticeable, since seemingly proper freight documents appeared in each case. Only an intensive examination and overall consideration of the documents revealed not only the economic folly of these transactions but also considerable discrepancies regarding individual freight times and delivery locations. Also, none of the companies involved in Western Europe had employees or storerooms for the wood. It was rather pure letterbox companies. With the support of OLAF, several meetings of the investigators were coordinated in 2010, which brought the investigations forward decisively. Investigations included day-to-day co-ordination of arrests and search warrants in a total of five European countries through mutual assistance.

\subsection{Features of Illicit Trade of Tobacco Products}

The illegal cross-border distribution covers a number of illegal activities, mainly illegal import or export of original cigarettes or counterfeit products, the purchase of unbranded, illegally manufactured products or "cheap whites" and also bootlegging. ${ }^{160}$

Main routes for smuggling to the Germany are the land route from Asia via eastern European countries (Baltic countries, Poland, Romania) or via south-eastern European countries (Greece, Bulgaria), by sea from Asia, the United Arab Emirates, Dubai and South America to harbors (mainly Hamburg) and by air, often used to smuggle tobacco products from within the European Union. The routes by land, by sea and partly by air change regularly dependent on the less risky way to their European destination.

\footnotetext{
${ }^{159}$ Koziolek (2015a), p. 211.

${ }^{160}$ The following information is mainly based on the reports of Maffei and Markopoulou (2014a), pp. 43 ff.; Maffei and Markopoulou (2014b), pp. 35 ff. See also Sinn (2016), pp. 51 ff.; Sinn (2018b). See also Koziolek (2015a), p. 211.
} 
A very large number of the cigarettes smuggled to Germany are purchased on the Vietnamese markets in the Czech Republic. ${ }^{161}$ Whereas in the past often counterfeit cigarettes from Asia were discovered in Germany in recent years more often legally produced cigarettes similar to well-known brands are found, often arriving from the United Arab Emirates, Dubai and Singapore. On the land routes cigarette smuggling is often carried out in trucks declared as empty or loaded with camouflage cargo, other methods include manipulated transit procedures, supposed travel and also the unlawful removal from a bonded warehouse or during a transit procedure. ${ }^{162}$ Increasingly vans as smaller, quicker and more flexible vehicles are use, as the damage in cases of detection is not as high as if a truck is confiscated. At the PolishGerman border also a substantial number of pedestrians smuggle cigarettes.

Retail selling occurs at different places, for example in the street, at flea markets, in public parks, near supermarkets, rarely in shops next to legal products. Germany is still one of the main destination countries for Jin Ling cigarettes. The Vietnamese cigarettes market and other Eastern European flea markets in Berlin now exist for decades, but trade places have been reduced substantially. Groups who involved in the smuggling trade are well-organized, often working together in loose criminal networks. The (street) vendors are acting very carefully and inconspicuously, which makes investigations difficult. They often only carry a small number of cigarette cartons at one time, so that only a few cartons are usually confiscated if they are detected.

The illegal market also includes the smuggling of branded products, the sale of cheapwhites, and the manufacture and sale of counterfeit cigarettes. The so-called bootlegging describes the purchase of cigarettes in a low-tax country, which are introduced beyond the permissible free allowance for personal use into another country usually with a higher tax rate such as Germany, and/or the imported cigarettes are resold in another country, without the on-site pay taxes due. ${ }^{163}$

Illicit trading of tobacco products has a close relationship to organized crime. ${ }^{164}$ Among all tax and custom offence activities of groups involved in organized crime, they have been most engaged in illicit trade of tobacco products. Although customs and tax offences are not the main field of organized criminal activity (around 10\%), customs and tax offences account for the highest amounts of losses for the treasury. ${ }^{165}$ Especially in regard to illicit whites organized crime groups play a major role as these cigarettes are produced on industrial scale in large production sites, connected to sophisticated logistics and distribution channels. ${ }^{166}$

\footnotetext{
${ }^{161} \operatorname{Sinn}(2018 b)$.

${ }^{162}$ Müller (2018), p. 2667.

${ }^{163}$ Knickmeier (2016), pp. 430-431.

${ }^{164}$ See Sinn (2018a), pp. 17 ff.; Sinn (2018b).

${ }^{165}$ Bundeskriminalamt, Organisierte Kriminalität, Bundeslagebild 2017, Wiesbaden April (2018).

${ }^{166}$ Sinn (2018b).
} 


\subsection{Characteristics of Perpetrators of Illicit Trade of Tobacco}

There is not much data available on the characteristics of perpetrators. Official statistics provide the nationality, the sexe of the perpetrator and if prior convictions exist. In regard to offenses of the $\mathrm{AO}$ the perpetrator is in $72 \%$ of the cases male, in $67 \%$ a German national and has in $26 \%$ of the cases a prior conviction (of any kind). ${ }^{167}$

Additional information stems from research studies. Perpetrators of illicit trade of tobacco can be subdivided as follows: ${ }^{168}$ small smugglers (e.g. tourists who carry cigarettes beyond their own needs or for resale across national borders with them), smugglers in groups working together across borders without a permanent connection (and were relations are formed through family or friends or through business relationships, often with close ties to the home country) and organized smugglers organized hierarchically into well-organized and profitable networks.

The trafficking of cigarettes involves very divers actors, from private travelers to professional distributors. ${ }^{169}$ According to a study in the 1990s on 216 offenders in Berlin, 93.4\% were non-German nationals (mainly Vietnamese nationals on retail level and Polish nationals within the supply chain). ${ }^{170}$ Only $11.7 \%$ of all suspects were women. ${ }^{171}$ The average age was $27 .{ }^{172}$ The offenders' previous criminal records were not of a severe nature. ${ }^{173}$ To them, illicit trade in tobacco was more of an additional income than an alternative to legal employment. ${ }^{174}$ The information was gathered in the city of Berlin, which implies factors that only come to play in this specific region. ${ }^{175}$

\subsection{Trends in Illicit Trade of Tobacco Products}

In the last years a significant cutback in the amount of confiscated cigarettes can be seen (see Tables 10 and 11). This goes along with a steady decrease in tobacco consumption since 2000, indicating that tobacco control policies have been successful. ${ }^{176}$

\footnotetext{
${ }^{167}$ Statistisches Bundesamt (Destatis) (2018b).

${ }^{168}$ Knickmeier (2016), p. 430.

${ }^{169}$ See von Lampe (2011), p. 151.

${ }^{170}$ von Lampe (2005), p. 222.

${ }^{171}$ von Lampe (2005), p. 222.

${ }^{172}$ von Lampe (2005), p. 222.

${ }^{173}$ von Lampe (2005), p. 222.

${ }^{174}$ von Lampe (2005), p. 222.

${ }^{175}$ von Lampe (2005), p. 221.

${ }^{176}$ Kuntz et al. (2017), p. 82.
} 
In the fight against contraband legal cigarettes legal provisions for supply chain security and track-and-trace systems were successful. Yet, illicit whites evade such regulations. ${ }^{177}$ The challenge of the fight against illicit whites is their raison d'êtrenamely illicit trade. ${ }^{178}$ These cigarettes are manufactured outside legal frameworks and do not enter regulated markets. This means, that they are not subject to production standards, consumer protection regulations or tobacco regulations. Insofar, police and criminal investigations seem to be the most effective measures in that regard.

Also, the organized crime dimension has become a major factor in this regard. The globalization of organized crime and the "professionalization" of respective groups enable large-scale counterfeit and contraband of various goods, in particular easily tradeable goods such as cigarettes. ${ }^{179}$ This means that organized crime is not just a specific form of participation in crime, but mainly an international and major threat to public security. This is especially true when established structures are used to broaden the scope of business, e.g., by also smuggling drugs or other substances. Insofar, more attention and emphasis needs to be put on the fight against structures of organized crime.

\section{Preventive Measures}

German prevention strategy against illicit trade of tobacco products mainly builds on criminalizing illicit tobacco trade as a tax offense and by providing the respective authorities (mainly the custom authorities) with financial and staff resources that in many aspects go beyond normal police resources. ${ }^{180}$ Insofar the authorities already mentioned (see supra B.) in regard to repressive measures are also entrusted with the prevention of illicit trading. Yet, the main strategy in recent years is to reduce tobacco consumption as a whole and thus reduce the incentives for illicit trading because of a decreased number of consumers. Tobacco consumption is regarded as a serious health risk and legal measures limit advertising tobacco products and provide for special notifications on health risks, ${ }^{181}$ although the German legislator is rather reluctant to proactively take measures. ${ }^{182}$

In order to better fight illicit trading the German legislator has transposed Regulation (EU) 2018/574, Delegated Regulation (EU) 2018/573 and Commission

\footnotetext{
${ }^{177} \operatorname{Sinn}(2018 b)$.

${ }^{178} \operatorname{Sinn}(2018 b)$.

${ }^{179} \operatorname{Sinn}(2018 b)$.

${ }^{180}$ Allen (2013).

${ }^{181}$ Meyer (2006), p. 217; Mons and Pötschke-Langer (2010), p. 144; Runkel, (2018), p. 232; Schaller and Mons (2018), p. 1429.

${ }^{182}$ See Schaller and Mons (2018), p. 1429.
} 
Implementing Decision (EU) 2018/576 into German law in April 2019. ${ }^{183}$ This has laid down basic rules for a system of traceability and security features by labeling tobacco products with an individual identification feature and a forgery-proof security feature. The traceability system aims to track the movement of these products so that they can be tracked across the European Union. In addition, the introduction of security features shall make it easier to verify that tobacco products are genuine.

\section{Cooperation}

Close cooperation between the authorities is the key element for successfully fighting illicit trade of tobacco goods. This means first hand that the custom offices at the borders and the custom investigation service have to work closely together. With the reform of the customs administration under the roof of the General Customs Directorate in 2015 steps have been taken that an effective cooperation can take place.

In regard to other authorities (such as the state and federal police offices and prosecution services) a close cooperation is especially enabled by the legal institution of administrative assistance. This institution shall enable the efficient handling of cases where tasks and powers have been distributed among different authorities. Specific aspects, especially the exchange of information are regulated explicitly in the respective legislation (e.g. $\S \S 6-16 \mathrm{ZFdG}$ ). These rules amend the basic regulations. ${ }^{184}$ There exist also special data banks such as the custom investigation information system (Zollfahndungsinformationssystem, see $\S 11 \mathrm{ZFdG}$ ), enabling a central storage of vital information for investigations. In general, authorities questioned to provide information or help have an obligation to cooperate with the requesting authority.

As in all border cases a close cooperation with neighboring countries (such as Poland) is vital and has been intensified in recent years in regard to mutual information and assistance. ${ }^{185}$ Especially organized crime cases cannot be conducted without investigations abroad. In regard to this cooperation with foreign countries, international institutions mainly the European ones have become indispensable: ${ }^{186}$ Interpol, Europol, Eurojust and above all OLAF are of particular importance for

\footnotetext{
${ }^{183}$ Erstes Gesetz zur Änderung des Tabakerzeugnisgesetzes of 29. April 2019, BGB1. I p. 514.

${ }^{184}$ See art. 35 para. $1 \mathrm{GG}$ (administrative assistance between federal and state authorities) as well as $\S 4$ of the federal administrative procedure act (Bundesverwaltungsverfahrensgesetz) and the similar regulations in the state administrative procedure acts (Landesverwaltungsverfahrensgesetze).

${ }^{185}$ See e.g. on form of cooperation von Lampe and Zurakowska (2017), p. 403; see also Calderoni et al. (2013), pp. $49 \mathrm{f}$.

${ }^{186}$ Koziolek (2015b), p. 719. See also Mersmann (2015), pp. $202 \mathrm{ff}$.
} 
anti-trafficking cases. ${ }^{187}$ Without the logistical support of these authorities a successful fight against organized crime would not have been possible, such as the above mentioned cases show (supra C. IV.).

Weaknesses in practice exist in the areas of resources, communication, organization and technology. ${ }^{188}$ Mobilization of personnel is often a problem in larger investigations (especially in regard to complex organized crime cases), worsened if disputes among the authorities over competencies exist. ${ }^{189}$ Communication is often not fast or comprehensive enough, sometimes with problems because of differing technical equipment or technical standards.

\section{General Aspects and Conclusion}

Regulating the illicit trade of tobacco products is closely connected to the regulation of the legal market. The relationship of the markets are not exactly clear, but there is on overlap of the legal and illegal market insofar as changes in the condition of the legal market has effects on the illegal one (and to a certain extent vice versa). ${ }^{190}$ One aspect to influence the market is taxing tobacco products. This is generally regarded to be among the most efficient instruments against tobacco consumption. ${ }^{191}$ Insofar raising taxes reduces overall consumption as some give up smoking completely or at least reduce consumption, ${ }^{192}$ especially in regard to vulnerable groups such as teenagers or pregnant women. ${ }^{193}$ Besides this effect consumers refer to cheaper product or alternative tobacco products not taxed equally. ${ }^{194}$ Referring to alternative products of course only works as long as their taxes are not raised, too. ${ }^{195}$ In addition, to a certain extent people refer to the illegal market, ${ }^{196}$ although it is unclear how big this effect is. ${ }^{197}$ From a fiscal point of view the effect on raising

\footnotetext{
${ }^{187}$ Koziolek (2015a), p. 211.

${ }^{188}$ Hoser (2013), p. 8.

${ }^{189}$ Hoser (2013), p. 8.

${ }^{190}$ Mersmann (2015), p. 82.

${ }^{191}$ Effertz and Schlittgen (2013), pp. e95-e100; Hanewinkel and Isensee (2003a), p. 395; Hanewinkel and Isensee (2003b), p. 168; Hanewinkel and Isensee (2007), p. 26; Isensee and Hanewinkel (2004), p. 771; see also Bräuninger and Stiller (2010), p. 21.

${ }^{192}$ Hanewinkel and Isensee (2005), pp. 9, 13; Schwarz (2009), p. 235.

${ }^{193}$ Richter and Klopprogge (2018), p. 400.

${ }^{194}$ Schwarz (2009), p. 235.

${ }^{195}$ Schwarz (2009), p. 235; Wigger (2011), pp. 39-40.

${ }^{196}$ Groneberg and Haustein (2008), p. 646; Schwarz (2009), p. 235.

${ }^{197}$ Major effects are seen by Bräuninger and Stiller (2010). No effect see: Effertz and Schlittgen (2013). See also Mersmann (2015), pp. $91 \mathrm{ff}$. on the complex relationship between tax and illegal market, that has not been taken into account in major studies (ibid 187-198), concluding that in some cases tax increases can also reduce illegal market activities.
} 
taxes is quite neutral. ${ }^{198}$ From a criminal law/policy perspective the effect on the illegal market is at least not substantial (if not even neglectable). ${ }^{199}$ There is no general substitution effect of smokers turning from consumption of legal cigarettes to smuggled ones. Insofar higher taxes are a suitable element in reducing tobacco consumption and do not foster a major criminal market. ${ }^{200}$ Altogether, the existing German tobacco tax regime is quite successful in achieving several (tax) aims simultaneously: falling consumption with steady tax revenues and also a tackling the consumption of non-domestic taxed tobacco, especially smuggled goods. ${ }^{201}$

Nonetheless, there is an illegal market and tax changes may have some minor effects on it, so that illicit trade of tobacco products needs to be addressed by the legislator. Current German legislation with its criminal and administrative offenses insofar appears to cover the phenomena sufficiently. In practice, the fight against smuggling with intensified efforts in recent years, has been more successful than years before. ${ }^{202}$ For the future a constant high level of controls in border regions is necessary in order to continue this successful path, what also means in lack of institutionalized border controls within the EU/Schengen area that alternative control mechanism have to developed further. Special attention has to be put to organized crime, although this is no specific problem of illicit trade in tobacco products. Insofar, the coordination of custom authorities with their special focus on taxes and customs and general police and prosecution authorities (covering the general phenomena of organized crime) could be improved especially when organized crime groups cover several areas of business (from tobacco trading over counterfeiting other products to smuggling drugs and persons), some of them also partly legal. ${ }^{203}$ Also, international cooperation should be improved in order to allow timely crossborder investigations. $^{204}$ The legislator could involve tobacco producers and sellers more in compliance efforts, but should refrain from further integrating them into law enforcement efforts as long as there is a suspicion of them being involved in such illegal activities. ${ }^{205}$

\footnotetext{
${ }^{198}$ Schwarz (2009), p. 242.

${ }^{199} \mathrm{~A}$ pure speculation (and not empirically founded) is the assumption by Bräuninger and Stiller (2010), pp. 21-22 that the expansion of the consumption of cigarettes not taxed has a selfreinforcing effect insofar as a higher proportion of illegal cigarettes increases the acceptance of consumptions. Vice versa decreases the illegality of a certain behavior its general social acceptance. ${ }^{200}$ Effertz and Schlittgen (2013); Groneberg and Haustein (2008), pp. 646-647.

${ }^{201}$ See Steidl and Wigger (2018), p. 331 seeing even a decrease in smuggled goods and pointing out that is central that the tax allows for a differentiation so that a price differential arises between high and low price cigarettes and fine-cuts taxation does not come close to cigarette taxation as in this way, low-priced cigarettes and fine cuts remain an alternative to non-domestically-taxed cigarettes (and also promote supplier competition and product diversity).

${ }^{202}$ Only see Steidl and Wigger (2018), p. 321 who state that the proportion of smuggled cigarettes has dropped since 2009. More cautios is the evaluation by Calderoni et al. (2013), pp. $45 \mathrm{ff}$.

${ }^{203}$ For the importance of cooperation see also Calderoni et al. (2013), pp. 81, 85.

${ }^{204}$ Hoser (2013), p. 4.

${ }^{205}$ See e.g. Richter and Klopprogge (2018), p. 400; Evans-Reeves et al. (2015), pp. e168-e177.
} 
In order to further address the problem of illicit trading tobacco products harmonizing taxes (and selling prices) within the European Union could reduce crossborder-shopping and also smuggling activities. ${ }^{206}$ A larger effect would be achieved by generally reducing consumption, what equally affects the legal and illegal market. In this regard health measures are of great importance. ${ }^{207}$ Banning smoking in public places (such as restaurants), restricting advertising and sponsoring and increasing awareness in regard to the risk of smoking have helped reducing consumption and as consequence the legal and illegal market already substantially, although Germany's efforts are not more than average. ${ }^{208}$ Insofar, further public health legislation would probably be the most effective measure to address this specific criminal phenomenon.

\section{References}

Adams M, Effertz T (2011) Tabaksteuern, Schmuggel und unversteuerte Zigaretten: Zur Glaubwürdigkeit der "Entsorgungsstudie" der Tabakindustrie. Gesundheitswesen 73 (10):705-712

Allen E (2013) Illegaler Handel mit Tabakprodukten: und wie man ihn bekämpft. International Tax and Investment Center, Almaty

Bauer C (2018) Praktische Fragen im Zusammenhang mit dem organisierten "Schmuggel" von Tabakwaren. NZWiSt (Neue Zeitschrift für Wirtschafts-Steuer- und Unternehmensstrafrecht):85-90

Bender P (2001) Rechtsfragen um den Transitschmuggel mit Zigaretten. wistra (wistra-Zeitschrift für Wirtschafts- und Steuerstrafrecht):161-167

Bender P (2006) Der EuGH und das Zollstrafrecht. wistra (wistra-Zeitschrift für Wirtschafts- und Steuerstrafrecht):41-45

Bittmann F (2010) Telefonüberwachung im Steuerstrafrecht und Steuerhinterziehung als Vortat der Geldwäsche seit dem 1-1-2008. wistra (wistra-Zeitschrift für Wirtschafts- und Steuerstrafrecht): $125-130$

Bräuninger M, Stiller S (2010) Ökonomische Konsequenzen des Konsums von nicht in Deutschland versteuerten Zigaretten. HWWI Policy Paper 1-28. Hamburgisches WeltWirtschaftsInstitut (HWWI), Hamburg

Budde S (2019) Anmerkung zu einer Entscheidung des BGH, Beschluss vom 19.12.2017 (1 StR 56/17) - Zur Strafbarkeit der neutralen Beihilfe bei Steuerstraftaten. NZWiSt (Neue Zeitschrift für Wirtschafts-Steuer- und Unternehmensstrafrecht):27-28

Bundeskriminalamt (2018) Bundeslagebild Organisierte Kriminalität 2017. https://www.bka.de/ SharedDocs/Downloads/DE/Publikationen/JahresberichteUndLagebilder/ OrganisierteKriminalitaet/organisierteKriminalitaetBundeslagebild2017.pdf? blob $=$ publicationFile\&v $=3$. Accessed 15 May 2019

Calderoni F et al (2013) Factbook zum illegalen Handel mit Tabakerzeugnissen: Deutschland. http://www.transcrime.it/wp-content/uploads/2013/11/Germany-Factbook-on-the-ITTP-Ger man.pdf. Accessed 15 May 2019

\footnotetext{
${ }^{206}$ Wigger (2011), p. 40.

${ }^{207}$ See, e.g., Wimmer (2013), pp. 111 ff.; Deutsches Krebsforschungszentrum (2010).

${ }^{208}$ Calderoni et al. (2013), pp. 31 ff. See also the rating with Germany on 33th place among 35 European countries, https://www.tobaccocontrolscale.org/results-last-edition/.
} 
Deimel K (2019) Art. 87 UZK. In: Dorsch E, Rüsken R (eds) Zollrecht. Recht des grenzüberschreitenden Warenverkehrs. Kommentar. Loose-leaf commentary, 161st supplementary delivery. Accessed 15 May 2019. Stollfuß, Bonn

Deutsches Krebsforschungszentrum (ed) (2010) Illegaler Zigarettenhandel und seine wirksame Bekämpfung zum Gesundheitsschutz der Bevölkerung. Deutsches Krebsforschungszentrum, Heidelberg

Effertz T, Schlittgen R (2013) Zigarettenpreise, Tabaksteuern und der Anteil an Schmuggelzigaretten in Deutschland. Gesundheitswesen 75(6):e95-e100

Evans-Reeves KA, Hatchard JL, Gilmore AB (2015) 'It will harm business and increase illicit trade': an evaluation of the relevance, quality and transparency of evidence submitted by transnational tobacco companies to the UK consultation on standardised packaging 2012. Tob Control 24(e2):e168-e177

Fehn BJ (2006) Überblick über das Steuerstrafverfahren (Zoll). In: Wamers P, Fehn BJ (eds) Handbuch Zollfahndung. Otto Schmidt, Köln. Chapter B

Fezer K-H (2009) Markenrecht. Beck'sche Kurz-Kommentare, 4th edn. Beck, München

Gallagher AWA et al (2018) Tobacco industry data on illicit tobacco trade: a systematic review of existing assessments. Tob Control:1-12. https://doi.org/10.1136/tobaccocontrol-2018-054295

Groneberg JDA, Haustein K-O (eds) (2008) Tabakabhängigkeit: Gesundheitliche Schäden durch das Rauchen, 2nd edn. Springer-Verlag, Berlin

Häberle P (2018) § 12e ZollVG. In: Erbs/Kohlhaas (ed), Strafrechtliche Nebengesetze. Loose-leaf commentary, 221 supplementary delivery (August 2018). C.H.Beck, München.

Hadamitzky A, Senge L (2018) § 370 AO. In: Erbs, Kohlhaas (eds) Strafrechtliche Nebengesetze. Loose-leaf commentary, 221st supplementary delivery (August 2018). C.H.Beck, München

Hanewinkel R, Isensee B (2003a) Der Zusammenhang zwischen Preis und Konsum von Zigaretten: Eine Analyse vorliegender Studien und Implikationen für die Tabakkontrollpolitik. In: Rumpf H-J (ed) Alkohol und Nikotin: Frühintervention, Akutbehandlung und politische Maßnahmen. Lambertus-Verlag, Freiburg im Breisgau, pp 395-411

Hanewinkel R, Isensee B (2003b) Umsetzung, Akzeptanz und Auswirkungen der Tabaksteuererhöhung in Deutschland vom 1.Januar 2002. SUCHT 49(3):168-179

Hanewinkel R, Isensee B (2005) Umsetzung, Akzeptanz und Auswirkungen der Tabaksteuererhöhung vom 1. Dezember 2004: Untersuchung im Auftrag des Bundesministeriums für Gesundheit und Soziale Sicherung (Juli 2005)

Hanewinkel R, Isensee B (2007) Auswirkungen von Tabaksteuererhöhungen in Deutschland. Public Health Forum 15(1):26-28

Harder M (2014) Kapitel: Zoll. In: Wabnitz H-B, Janovsky T (eds) Handbuch des Wirtschafts- und Steuerstrafrechts, 4th edn. Beck, München, $\mathrm{p} 22$

Hefendehl R (2015) 263 StGB. In: Joecks W, Schmitz R (eds) Münchener Kommentar zum Strafgesetzbuch, 2nd edn. Beck, München

Heuel I (2016) § 378 AO. In: Kohlmann G (ed) Steuerstrafrecht §§ 377-412 AO. Loose-leaf commentary, 54th supplementary delivery (April 2016). Otto Schmidt, Köln

Hilgers-Klautzsch B (2017) § 375 AO. In: Kohlmann G (ed) Steuerstrafrecht: Kommentar zu den $\S \S 369$ - 412 AO 1977. Otto Schmidt, Köln

Hoser M (2013) Bekämpfung der Organisierten Kriminalität: Unter besonderer Berücksichtigung der Rolle des Zigarettenschmuggels. Tagungsbericht, Bildungszentrum Wildbad Kreuth 13. bis 15 November 2013, Hanns-Seidel-Stiftung. https://www.hss.de/fileadmin/media/downloads/ Berichte/131113_TB_Kriminalitaet.pdf. Accessed 15 May 2019

Isensee B, Hanewinkel R (2004) Evaluation der Tabaksteuererhöhung vom 1. Januar 2003 (2004). Bundesgesundheitsblatt - Gesundheitsforschung - Gesundheitsschutz 47(8):771-779

Jäger M (2000) Voraussetzungen der Strafbarkeit von Bankangestellten wegen Beihilfe zur Steuerhinterziehung durch Mithilfe beim anonymen Kapitaltransfer von Kunden. wistra (wistra-Zeitschrift für Wirtschafts- und Steuerstrafrecht):344-348

Jäger M (2009) Die Auswirkungen der Osterweiterung der Europäischen Union auf das deutsche Steuerstrafrecht. In: Böse M, Sternberg-Lieben D (eds) Grundlagen des 
Straf- undStrafverfahrensrechts. Festschrift für Knut Amelung zum 70. Geburtstag. Duncker \& Humblot GmbH, Berlin, pp 447-472

Jäger M (2015) § 370 AO. In: Joecks W, Jäger M, Randt K (eds) Steuerstrafrecht: Mit Zoll- und Verbrauchsteuerstrafrecht; Kommentar $\S 369$ - 412 AO, § 32 ZollVG, 8th edn. C.H. Beck, München

Jäger M (2017) Aus der Rechtsprechung des Bundesgerichtshofs zum Steuerstrafrecht: Teil 2/2. NStZ (Neue Zeitschrift für Strafrecht):517-523

Jäger M (2018) § 370 AO. In: Gersch E-M et al (eds) Abgabenordnung: Einschließlich Steuerstrafrecht, 14th edn. C.H. Beck, München

Knickmeier S (2016) Der Zigarettenschmuggel, das Recht und die Moral. In: Neubacher F, Bögelein N (eds) Krise - Kriminalität - Kriminologie. Forum Verlag Godesberg GmbH, Mönchengladbach, pp 429-439

Koziolek M (2015a) Zigarettenschmuggel. Kriminalistik:211-217

Koziolek M (2015b) Zigarettenschmuggel und Organisierte Kriminalität: Ein positives Beispiel deutsch-griechischer Zusammenarbeit. Kriminalistik:719-726

KPMG (2017) Project SUN: a study of the illicit cigarette market in the European Union, Norway and Switzerland 2017 results

Krause DM, Prieß H-J (2014) § 34 Zollstrafrecht. In: Volk K (ed) Münchener Anwalts-Handbuch Verteidigung in Wirtschafts- und Steuerstrafsachen, 2nd edn. C.H. Beck, München

Küchenhoff B (2018) Strafbares Entziehen aus der zollamtlichen Überwachung - die Renaissance des Verbotsbannbruchs. NZWiSt (Neue Zeitschrift für Wirtschafts-Steuer- und Unternehmensstrafrecht):90-95

Kuntz B et al (2017) Zeitliche Entwicklung des Absatzes von Tabakwaren in Deutschland. J Health Monit:82-89

Kutschke P (2018) § 143a MarkenG. In: Kur A, von Bomhard V, Albrecht F (eds) Markenrecht: Markengesetz, Verordnung über die Unionsmarke (UMV): Kommentar, 2nd edn. C.H. Beck, München

Land Nordrhein-Westfalen (2013) Entwurf eines Gesetzes zur Einführung der strafrechtlichen Verantwortlichkeit von Unternehmen und sonstigen Verbänden. https://www.landtag.nrw.de/ portal/WWW/dokumentenarchiv/Dokument/MMI16-127.pdf. Accessed 15 May 2019

Leitner W et al (eds) (2017) Wirtschafts- und Steuerstrafrecht. Nomos, Baden-Baden

Lenz J (2006) Datenschutz. In: Wamers P, Fehn BJ (eds) Handbuch Zollfahndung. Otto Schmidt, Köln. Chapter C

Linke H-D (2004) Das Zollkriminalamt: Eine geheimnisvolle, unsichtbare und mächtige Strafverfolgungsbehörde? Lang, Frankfurt am Main

Maffei S, Markopoulou L (2014a) FIDUCIA - New European crimes and trust-based policy, vol 2. ISBN 978-618-81128-4-1

Maffei S, Markopoulou L (2014b) FIDUCIA - New European crimes and trust-based policy, vol 3. ISBN 978-618-81128-8-9

Mersmann H (2015) Die ökonomische Analyse des Zigarettenschmuggels. Dissertation, Universität Hamburg.

Meyer K (2006) Takakprävention. Prävention und Gesundheitsförderung 1(4):217-218

Mons U, Pötschke-Langer M (2010) Gesetzliche Maßnahmen zur Tabakprävention. Bundesgesundheitsblatt - Gesundheitsforschung - Gesundheitsschutz 53(2):144-151

Müller V (2018) Zigarettenschmuggel. In: Möllers HW, Kastner M (eds) Wörterbuch der Polizei, 3rd edn. Beck, München, pp 2667-2668

Norddeutscher Rundfunk (2018) Bislang größter Zigarettenschmuggel aufgeflogen (18 April 2018).

https://www.ndr.de/nachrichten/schleswig-holstein/Bislang-groessterZigarettenschmuggel-aufgeflogen,zoll818.html. Accessed May 2019

Retemeyer A, Möller T (2015) Kapitel 20: Zölle und Marktordnungen. In: Adick M, Bülte J (eds) Fiskalstrafrecht: Straftaten gegen staatliche Vermögenswerte. Müller, Heidelberg, pp 554-597 
Richter UH, Klopprogge M (2018) Unternehmensverantwortung in der Tabakindustrie: Strategische Herausforderungen und Lösungsansätze. In: Bungard P (ed) CSR und Geschäftsmodelle. Springer, Berlin, pp 393-406

Runkel K (2018) Stolpersteine der Tabakwerbung. IPRB (Der IP-Rechts-Berater):232-235

Schaller K, Mons U (2018) Tabakprävention in Deutschland und international. Bundesgesundheitsblatt - Gesundheitsforschung - Gesundheitsschutz 61(11):1429-1438

Schlagowski J (2018) Originäre Verbandsstrafbarkeit. Nomos, Baden-Baden

Schmitz R, Wulf M (2015) 370 AO. In: Joecks W, Schmitz R (eds) Münchener Kommentar zum Strafgesetzbuch, 2nd edn. Beck, München

Schwarz P (2009) Optionen einer rationalen Regulierung des Tabakkonsums: Die Vorteile eines liberalen Paternalismus. Perspektiven der Wirtschaftspolitik 10(2):235-251

Sinn A (2016) Organisierte Kriminalität 3.0. Springer, Berlin

Sinn A (2018a) Wirtschaftsmacht Organisierte Kriminalität: Illegale Märkte und illegaler Handel. Springer, Berlin

Sinn A (2018b) The link between illicit tobacco trade and organised crime (Fighting illicit tobacco, European Commission, Brussels, 23 March 2018). https://www.eesc.europa.eu/en/news-media/ presentations/link-between-illicit-tobacco-trade-and-organised-crime. Accessed 15 May 2019

Statistisches Bundesamt (Destatis) (2018a) Rechtspflege: Staatsanwaltschaften: Fachserie 10 Reihe 2.6

Statistisches Bundesamt (Destatis) (2018b) Rechtspflege: Strafverfolgung: Fachserie 10 Reihe 3

Steidl F, Wigger BU (2018) Optimale Besteuerung von Tabakwaren. List Forum für Wirtschaftsund Finanzpolitik 44(3):311-333

Stoklosa M (2016) Is the illicit cigarette market really growing?: The tobacco industry's misleading math trick. Tob Control 25(3):360-361

Streinz R (2017) "Gutachten zur Frage der Verpflichtung der Bundesrepublik Deutschland aus Artikel 13 des Rahmenübereinkommens der WHO zur Eindämmung des Tabakgebrauchs (FCTC) zum Erlass der im Entwurf eines Gesetzes zur Änderung des Tabakgesetzes vorgesehenen Ausweitung der Werbeverbote und -beschränkungen für Tabakerzeugnisse und verwandte Erzeugnisse, soweit Verfassungsrecht nicht entgegensteht" (of 27 September 2017), https://www.bmel.de/SharedDocs/Downloads/Ernaehrung/Gesundheit/Tabakrichtlinie/ Gutachten_BMEL_Art13_FCTC.pdf?_blob=publicationFile. Accessed 15 May 2019

Taschowsky P (2015) Illegale Aktivitäten in den Volkswirtschaftlichen Gesamtrechnungen: Möglichkeiten und Grenzen der Erfassung von Zigarettenschmuggel und Drogen. WISTA (Wirtschaft und Statistik):28-41

von Lampe K (2005) Explaining the emergence of the cigarette black market in Germany. In: van Duyne PC (ed) The organised crime economy: managing crime markets in Europe. Wolf Legal Publication, Nijmegen, pp 209-229

von Lampe K (2011) The illegal cigarette trade. In: Natarajan M (ed) International crime and justice. Cambridge University Press, Cambridge, pp 148-154

von Lampe K, Zurakowska A (2017) German-polish cross-border police cooperation: the many faces of crime for profit and ways of tackling it. In: van Duyne PC et al (eds) The many faces of crime for profit and ways of tackling it. Wolf Legal Publishers, Nijmegen, pp 403-423

Wachner P (2006) AWG/KWKG/CWÜ். In: Wamers P, Fehn BJ (eds) Handbuch Zollfahndung. Otto Schmidt, Köln. Chapter H

Weerth C (2018) Bekämpfung des Verbrauchsteuerschmuggels mit § 12e ZollVG, BDZ-Fachteil 4/2018: F19-F20. https://www.econstor.eu/bitstream/10419/177388/1/Weerth_ Verbrauchsteuerschmuggel_BDZ-Fachteil_4_2018.pdf. Accessed 15 May 2019

Wegner C (2015a) § 372 AO. In: Joecks W, Schmitz R (eds) Münchener Kommentar zum Strafgesetzbuch, 2nd edn. Beck, München

Wegner C (2015b) § 375 AO. In: Joecks W, Schmitz R (eds) Münchener Kommentar zum Strafgesetzbuch, 2nd edn. Beck, München 
Weidemann J (2014) Anmerkung zu EuGH, Urteil vom 03.07.2014 - Rs. C-165/13: Steuerschuldnerschaft bei Tabaksteuer. wistra (wistra-Zeitschrift für Wirtschafts- und Steuerstrafrecht):433-434

Weidemann J (2017) § 370 Abs. 1 Nr. 3 AO im funktionalen Zusammenhang mit dem Erklärungsdelikt des $§ 370$ Abs. 1 Nr. 2 AO. wistra (wistra-Zeitschrift für Wirtschafts- und Steuerstrafrecht):136-140

Weidemann J (2018) Tabaksteuerstrafrecht: Die Tabaksteuer als harmonisierte Verbrauchsteuer. https://www.jura.rub.de/sites/default/files/2018-06/Tabaksteuerstrafrecht_OnlineVersion.pdf. Accessed 15 May 2019

Weidemann J, Weidemann A (2005) Handeln und Unterlassen im Steuerstrafrecht: Warum der Begehungstatbestand der Steuerhinterziehung ( 370 Abs. 1 Nr. 1 AO) fast leer läuft. wistra (wistra-Zeitschrift für Wirtschafts- und Steuerstrafrecht):207-211

Wigger BU (2011) Zur schrittweisen Erhöhung der Tabaksteuer. Wirtschaftsdienst 91(1):39-41

Wimmer T (2013) Rauchen, ein ganz normales Konsumverhalten? Perspektiven und Analysen zur Erklärung des Zigarettenkonsums. Springer VS, Wiesbaden

Wirth J-C (2005) Verdachtslose Ermittlungen nach Zollverwaltungsgesetz. Lang, Frankfurt am Main

Zieschang F (2014) Das Verbandsstrafgesetzbuch. GA (Goltdammer's Archiv für Strafrecht):91-106

Zoll (2019) Pflichtverstöße, die das Verbringen betreffen - Art. 79 Abs. 1 a) UZK. https://www.zoll. de/DE/Fachthemen/Zoelle/Zollschuldentstehung/Pflichtverstoesse-Verbringen/ pflichtverstoesse-verbringen_node.html. Accessed 15 May 2019

Marc Engelhart currently holds a deputy professorship for criminal law and digitalization at the Ludwig-Maximilians-University Munich (winter term 2019/20 and summer term 2020). He is also a senior researcher at the Max Planck Institute for the Study of Crime, Security and Law in Freiburg i. Br. (Germany) where he is head of the section for business and economic criminal law and of the Max Planck Research Group on "The Architecture of Public Security Regulation". His main research focus is on business and economic criminal law, European and international criminal law, the law of criminal procedure, security studies and comparative criminal law.

Open Access This chapter is licensed under the terms of the Creative Commons Attribution 4.0 International License (http://creativecommons.org/licenses/by/4.0/), which permits use, sharing, adaptation, distribution and reproduction in any medium or format, as long as you give appropriate credit to the original author(s) and the source, provide a link to the Creative Commons licence and indicate if changes were made.

The images or other third party material in this chapter are included in the chapter's Creative Commons licence, unless indicated otherwise in a credit line to the material. If material is not included in the chapter's Creative Commons licence and your intended use is not permitted by statutory regulation or exceeds the permitted use, you will need to obtain permission directly from the copyright holder.

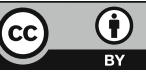

